\title{
Review Article \\ Role of Phytoremediation in Reducing Cadmium Toxicity in Soil and Water
}

\author{
Pooja Mahajan and Jyotsna Kaushal \\ Department of Applied Sciences, Chitkara University, Rajpura 140401, India \\ Correspondence should be addressed to Jyotsna Kaushal; jyotsna.kaushal@chitkara.edu.in
}

Received 30 May 2018; Accepted 24 September 2018; Published 23 October 2018

Academic Editor: You-Cheng Hseu

Copyright (C) 2018 Pooja Mahajan and Jyotsna Kaushal. This is an open access article distributed under the Creative Commons Attribution License, which permits unrestricted use, distribution, and reproduction in any medium, provided the original work is properly cited.

\begin{abstract}
Heavy metals are a noxious form of pollutants present in soil and water. A new plant-based solar energy driven technology, phytoremediation, emerges as eco-friendly and cost-effective approach to remove heavy metal from various media with the help of hyperaccumulating plant species. This review paper aims to provide information on phytoremediation and its mechanisms for heavy metal removal especially to focus on Cadmium (Cd) metal and highlights the role of various hyperaccumulating plants for $\mathrm{Cd}$ metal remediation in soil and water. It complies various field case studies which play the important role in understanding the $\mathrm{Cd}$ removal through various plants. Additionally, it pinpoints several sources and the effects of Cd and other technologies used for $\mathrm{Cd}$ remediation. This paper provides the recent development in mechanisms of Cd hyperaccumulation by different plants, in order to motivate further research in this field.
\end{abstract}

\section{Introduction}

In the present scenario, the most important concern of environmentalists is the alteration in biogeochemical cycles due to the variety of organic and inorganic pollutants released by manmade activities [1]. Along with the growth in industrialization, different remediation technologies were also coming into practice all-over the world to deal with different categories of pollutants. Among such pollutants, heavy metals are prime and critical contaminants in our surroundings. Heavy metals are continuing to exist for a prolonged period in nature as compared to other organic pollutants such as pesticides or petroleum by-products. So this makes the presence of heavy metals a matter of special concern. With the development of the global economy, different heavy metals in varying concentrations have gradually increased in environment thus resulting in degradation of the environment [2].

Heavy metals are highly noxious for all biotic components of the environment. Heavy metal contamination results either from the direct water source or through biomagnification. Sometimes in mining areas, high air concentrations also become a source of heavy metal contamination [3]. For instance, the Love Canal tragedy of the Niagara Falls in the USA explained the disastrous heavy metal effect on its human as well as animal population [4]. Several conventional technologies are being used for eradication of heavy metals, but these require a huge capital cost and have other disadvantages also. With the chemical method, not only heavy metals are eliminated but also valuable components of soil get degraded. Moreover, chemical methods generate a large amount of slurry and cost also per capita get increased [5].

A solution to this problem was suggested in terms of a new innovative eco-friendly technology known as phytoremediation which utilizes plants for treatment of pollutants. In literature, phytoremediation is mentioned as bioremediation, greener remediation or as botanical-remediation [6]. Another author defines phytoremediation as remediation of pollutants from the environment by converting those into less toxic form with the use of green plants [7]. According to Environment Protection Guide of USA, the term phytoremediation has been used since 1991 to publish different case studies where plants were utilized to remediate various types of contaminants [8]. Out of this broad category of pollutants, we have emphasized mainly on the remediation of Cd metal through phytoremediation technique due to its toxicity as detailed in this paper. We also compared other $\mathrm{Cd}$ 
TABLE 1: Hyperaccumulators reported for phytoremediation of heavy metals.

\begin{tabular}{|c|c|c|c|c|}
\hline Heavy metal & Plant & Mechanism & Medium & References \\
\hline \multirow{2}{*}{ As } & Pteris vittata & Phytoextraction & Soil & [15] \\
\hline & Piricum sativum & Phytostabilization & Soil & {$[16]$} \\
\hline \multirow{5}{*}{$\mathrm{Cd}$} & Oryza sativa & Phytoextraction & Soil & [17] \\
\hline & Vetiver grass & Phytostabilization & Soil & {$[18]$} \\
\hline & Lemna minor & Rhizofiltration & Water & {$[19]$} \\
\hline & Allium sativum & Phytoextraction & Hydroponic solution & {$[20]$} \\
\hline & Lemna minor & Rhizofiltration & Water & {$[19]$} \\
\hline \multirow{2}{*}{$\mathrm{Cr}$} & \multirow{2}{*}{ Brassica juncea } & Phytoextraction & Soil & {$[21]$} \\
\hline & & Rhizofiltration & Water & {$[22]$} \\
\hline \multirow{2}{*}{$\mathrm{Hg}$} & Marrubium vulgare & Phytoextraction & Soil & [23] \\
\hline & Pistia stratiotes & Rhizofiltration & Water & {$[24]$} \\
\hline \multirow{3}{*}{$\mathrm{Ni}$} & Alyssum lesbiacum & Phytoextraction & Soil & [25] \\
\hline & \multirow{2}{*}{ Agropyron elongatum } & Phytostabilization & Soil & {$[26]$} \\
\hline & & Rhizofiltration & Water & [27] \\
\hline \multirow{3}{*}{$\mathrm{Pb}$} & Chenopodium album & Phytoextraction & Soil & [28] \\
\hline & Vetiveria zizanioides & Phytostabilization & Soil & [29] \\
\hline & Hemidesmus indicus & Rhizofiltration & Water & {$[30]$} \\
\hline \multirow{3}{*}{ Se } & Brassica rapa $L$. & Phytoextraction & Soil & {$[31]$} \\
\hline & Lemna minor & Rhizofiltration & Water & {$[32]$} \\
\hline & Brassica spp. & Phytovolatization & Water & [33] \\
\hline $\mathrm{U}$ & Lolium perenne & Phytoextraction & Soil & [34] \\
\hline \multirow{2}{*}{$\mathrm{Zn}$} & Cynodon dactylon & Phytoextraction & Soil & {$[28]$} \\
\hline & Brassica juncea & Rhizofiltration & Water & [35] \\
\hline
\end{tabular}

remediation techniques with phytoremediation. This review paper also discusses the various mechanisms adopted by various plants to reduce $\mathrm{Cd}$ toxicity.

\section{Phytoremediation}

Plants practice different ways to remediate a wide range of contaminants in the environment. Certain plants act as "green livers" as they possess such worthy competence for the degradation of many adamant xenobiotics and act as the sink for noxious contaminants. This "solar driven" technology has the ability to remove contaminants such as heavy metals (As, $\mathrm{Cd}, \mathrm{Cu}, \mathrm{Cr}, \mathrm{Hg}, \mathrm{Ni}, \mathrm{Pb}, \mathrm{Se}, \mathrm{Zn}$, etc.), radioactive metals (Cs, $\mathrm{Sr}, \mathrm{U}$, etc.), and organic compounds (Benzopyrene pesticides (PAHs), Trichloroethylene (TCE), Trinitrotoluene (TNT), etc.). Phytoremediation plants must possess qualities like (1) rapid growth, (2) high biomass, (3) hairy and deep-root system, and (4) high bioaccumulation coefficient. Plants with extraordinary metal-accumulating power in their parts are described as hyperaccumulating plants. According to Baker, hyperaccumulating plants have the ability to uptake, translocate, assimilate, pile up, and tolerate high concentration of metals [9]. In literature, approximately 400 plant species have been reported as hyperaccumulators of different heavy metal.

Firstly, Brooks devised the term hyperaccumulator. According to him, hyperaccumulator defined as the plant which is accumulating efficiently $\mathrm{Ni}$ (approx. $1000 \mathrm{mg} \mathrm{kg}^{-1}$ ) in their upper portions [10]. If any plant was able to accumulate the heavy metal in its dry weight more than $0.1 \%$ then it is termed as hyperaccumulator [11] and if 50\% remediation ability in 24 hours then it is termed as a good phytoremediation agent [12]. But a hyperaccumulator should show tolerance to that heavy metal along with bioaccumulation of heavy metal. Hyperaccumulators should have the metal concentration of $0.001 \%(\mathrm{Hg}), 0.01 \%(\mathrm{Cd}$ and $\mathrm{Se}$ ), $1 \%(\mathrm{Mn}, \mathrm{Zn})$, and $0.1 \%$ ( $\mathrm{Al}, \mathrm{Cr}, \mathrm{Co}, \mathrm{Cu}, \mathrm{Pb}$, and $\mathrm{Ni}$ ) of the shoot dry weight [13] (Backer and Brooks, 1989). A very few and most common hyperaccumulator are listed in Table 1.

Hence, hyperaccumulator plants have mainly been reported from family Brassicaceae, Cunouniaceae, Caryophyllaceae, Asteraceae, Euphorbiaceae, Cyperaceae, Fabaceae, Lamiaceae, Violaceae, Poaceae, etc. [14]. Phytoremediation technology for heavy metal remediation involved different action mechanisms as shown in Figure 1.

2.1. Phytoextraction. Plants have the ability to phytoextract essential ( $\mathrm{Cu}, \mathrm{Mg}, \mathrm{Mo}, \mathrm{K}, \mathrm{Fe}, \mathrm{Mn}, \mathrm{Ni}, \mathrm{P}$, and $\mathrm{Zn})$ as well as nonessential metals ( $\mathrm{Se}, \mathrm{B}, \mathrm{Cd}, \mathrm{Co}, \mathrm{Cr}, \mathrm{Ag}$, and $\mathrm{Hg}$ ) required for plant growth. Nonessential metals are proven to be toxic to plants if present even in very low concentration and essential metals have also become noxious if present in more than the required quantity. In phytoextraction, plants ingest metals through roots and translocate the same to other parts. The main disadvantage of phytoextraction is that it is significant to only those sites which have low to medium amount of metal contamination as highly polluted sites prove to be noxious for the plant development [14]. The phytoextraction process depends mainly on the capability of 


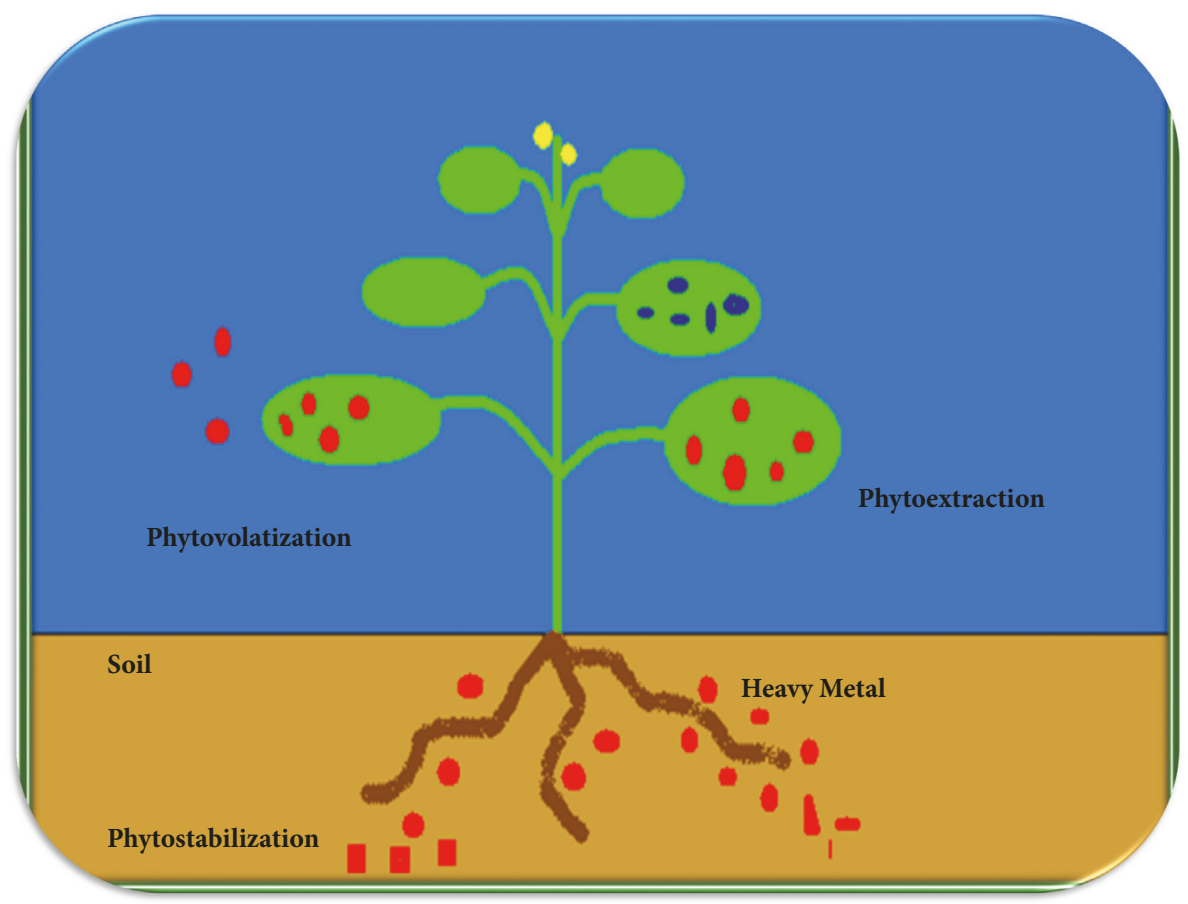

FIGURE 1: Phytoremediation mechanism adopted by plants to remediated heavy metals.

the plant (1) to eradicate metal on fast pace (2) to accumulate maximum amount of metals in aerial parts (3) to tolerate high metal concentrations and (4) to grow fast [36, 37]. Pteris vittata and Chenopodium albums have reported for phytoextraction of Arsenic and Lead, respectively [28, 38]. To increase bioavailability of metals, some chelating ligands like EDDS, EDTA, Succinic acid, Citric acid etc. were also added to contamination sites [18].

2.2. Rhizofiltration. Rhizofiltration mechanism is adopted by plants to remove heavy metals as well as radioactive metals like $\mathrm{Cd}, \mathrm{Cu}, \mathrm{Ni}, \mathrm{Pb}, \mathrm{Cr}, \mathrm{Cs}, \mathrm{As}, \mathrm{U}$, and $\mathrm{Sr}$ from aqueous solutions. In rhizofiltration, plant roots take up metal contamination from the wastewater streams or from wetlands. Suitability of the Plants for rhizofiltration depends upon the root system as roots filter metals from aqueous solution. Plants identified for adopting this mechanism have longer and hairy root systems of the considerable surface area. Indian mustard (Brassica juncea) and sunflower (Helianthus annuus) are favorable plants for rhizofiltration. Brassica effectively remediate $\mathrm{Pb}, \mathrm{Cd}, \mathrm{Cu}, \mathrm{Cr}, \mathrm{Ni}, \mathrm{Zn}$, and Helianthus rhizofiltered Ra and U [39].

2.3. Phytostabilization. Phytostabilization refers to the process in which a plant is able to immobilize metal in the resource and transform metallic toxic state to less toxic state. As a result migration of metals to other sites gets reduced [40]. Phytostabilization requires plants whose roots are able to develop into contamination zone and helps in immobilization of metal in soils either by root adsorption or by metal precipitation/ complexation/ reduction [41]. The highly noxious $\mathrm{Cr}(+6)$ gets transformed into $\mathrm{Cr}(+3)$, a less soluble and immobile form, through phytoremediation process [42]. Phytostabilization is found to be more effective in case of fine soils and high organic matter content [43]. Hence, phytostabilization does not even need removal of soil and disposal of contaminated biomass.

2.4. Phytovolatization. Phytovolatization is the eradication of pollutants by using plants converting the same to less toxic volatile form along with transpiration process using plants. Some organic pollutants and heavy metals such as arsenic, mercury, and selenium get volatilized by plants. In literature, macrophytes like Chara canescens (musk grass) and Arabidopsis thaliana were detailed for adopting phytovolatization [44]. Authors reported the eradication of $\mathrm{Hg}$ as $\mathrm{Hg}^{2+}$ ions which are less toxic forms of mercury. Tritium (the isotope of hydrogen) was stabilized as helium through phytovolatization [45]. Selenium found in the soil volatized as $\left(\mathrm{CH}_{3}\right)_{2} \mathrm{Se}$. This form of Se is 600 times less toxic than elemental Se [46].

\section{Cd: Sources, Speciation, Toxicity, and Chemistry}

Heavy metal Cd is widely distributed in water and soil as a nonessential toxic metal which occurs either in form of 0 or +2 oxidation state. It exists in nature as $\mathrm{Cd}(\mathrm{OH})_{2}, \mathrm{CdCO}_{3}$ and $\mathrm{CdSO}_{4}$. Cd also precipitates in the form of arsenates, phosphates, chromates, sulfides, etc. The permissible limit of $\mathrm{Cd}^{2+}$ in soil and plant is less than $1 \mathrm{mg} \mathrm{L}^{-1}$ and 0.005 $0.02 \mathrm{mg} \mathrm{L}^{-1}$ respectively, according to USEPA [47]. The sources and permissible limit of $\mathrm{Cd}^{2+}$ in water are detailed in Table 2. The Cd concentration in water and soil resources 
TABLE 2: Sources and permissible limits of Cd [49-52].

\begin{tabular}{|c|c|c|c|}
\hline Natural Sources & Industrial Sources & Uses & Permissible limit $\left(\mathrm{mg} \mathrm{L}^{-1}\right)$ \\
\hline $\begin{array}{l}\text { Coal combustion, iron and } \\
\text { steel production, } \\
\text { phosphate fertilizer } \\
\text { manufacture and use, } \\
\text { and zinc production, } \\
\text { volcanic activities }\end{array}$ & $\begin{array}{c}\text { Zinc smelting, } \\
\text { mining, waste } \\
\text { batteries, e-waste, } \\
\text { fuel combustion, } \\
\text { manufacturing of alloys, } \\
\text { pigments and dyes, textile } \\
\text { operations etc. }\end{array}$ & $\begin{array}{l}\text { Electroplating of steel, } \\
\text { Ni-Cd batteries, } \\
\text { cellular telephones, Laptop } \\
\text { computers and camcorders }\end{array}$ & $\begin{array}{c}0.003 \text { (IS 10500) } \\
0.003 \text { (WHO) } \\
0.005 \text { (USEPA) } \\
0.005 \text { (EU Standard) } \\
0.002 \text { (NHMRC, Australia) }\end{array}$ \\
\hline
\end{tabular}

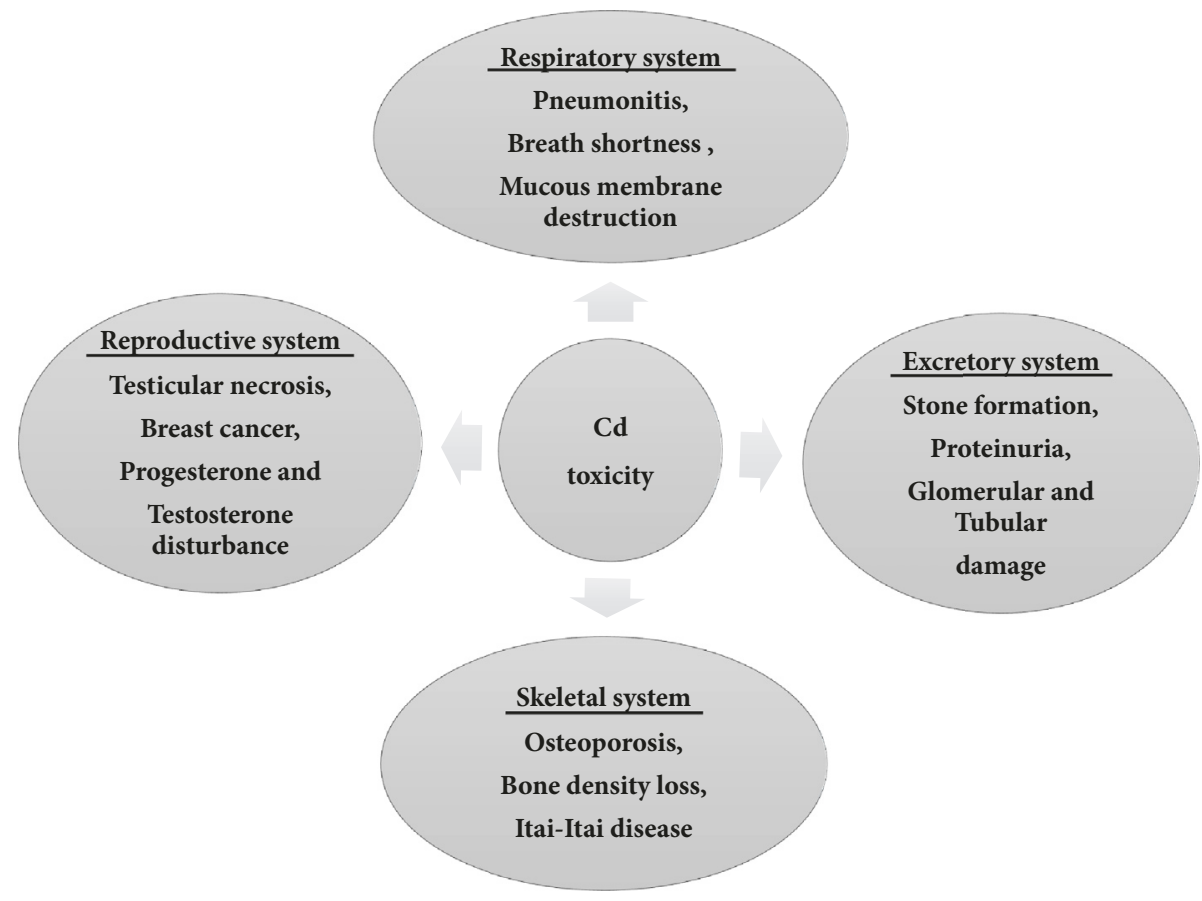

Figure 2: Cd effect on various organ system of human body.

gets increased day by day due to natural activities and anthropogenic activities [48].

Thus, the ecosystem gets contaminated either through direct $\mathrm{Cd}$ production or through secondary sources. It has been found that even a slight exposure to $\mathrm{Cd}$ results in the chronic effect on both animals and humans. In the human body, most of the Cd intake is through vegetable consumption [53]. An excessive amount of Cd dust causes multiple malfunctioning of organs (Figure 2).

$\mathrm{Cd}$ exposure to human bodies results in accumulation of $\mathrm{Cd}$ in the liver and kidneys which cause liver and renal malfunctioning and, on skeletal accumulation, results in Itai-Itai bone disease. A well-known case study on Jintsu river of Japan was due to Cd toxicity [54]. Once the Cd got accumulated in the human body, the estimation of its average half-life period is about 10 years [55] otherwise, in the environment, it is approximately 18 years [56]. Several physiological processes of plants like Nitrogen-metabolism and oxidative reactions were inhibited by Cd [57]. Presence of $\mathrm{Cd}$ in plants causes necrosis, leaf chlorosis, reduction in plant growth, and damage of photosynthetic machinery, especially photosystems PS-I and PS-II, which result into reduction in chlorophyll synthesis [58]. So, it is necessary to fetch an appropriate and a relevant solution to removal of $\mathrm{Cd}$ from the environment. Thus, the removal of nonessential metal such as Cd from environment becomes the area of interest for researchers.

\section{Existing Techniques for Remediation of Cd}

The removal of $\mathrm{Cd}$ from contaminated soil and water can be achieved by various physical, chemical, and biological methods as shown in Figure 3. The wastewater treatment of industries and remediation of contaminated soil are still based upon the physical and chemical methods in spite of disposal problems and high cost.

4.1. Physical Methods. In physical methods, membrane filtration and adsorption are mostly used for toxic metal ions remediation process. Cd was mainly adsorbed via adsorbents such as activated Carbon, synthetic $\mathrm{Al}_{2} \mathrm{O}_{3}$, low-cost oxides/hydroxides of $\mathrm{Al}, \mathrm{Mg}$, or $\mathrm{Fe}$, and waste product of agriculture [59-61]. High loading capacities adsorbents (> $90 \mathrm{mg} \mathrm{g}^{-1}$ ) such as silicate, wheat bran, fig leaves, pea peel, 


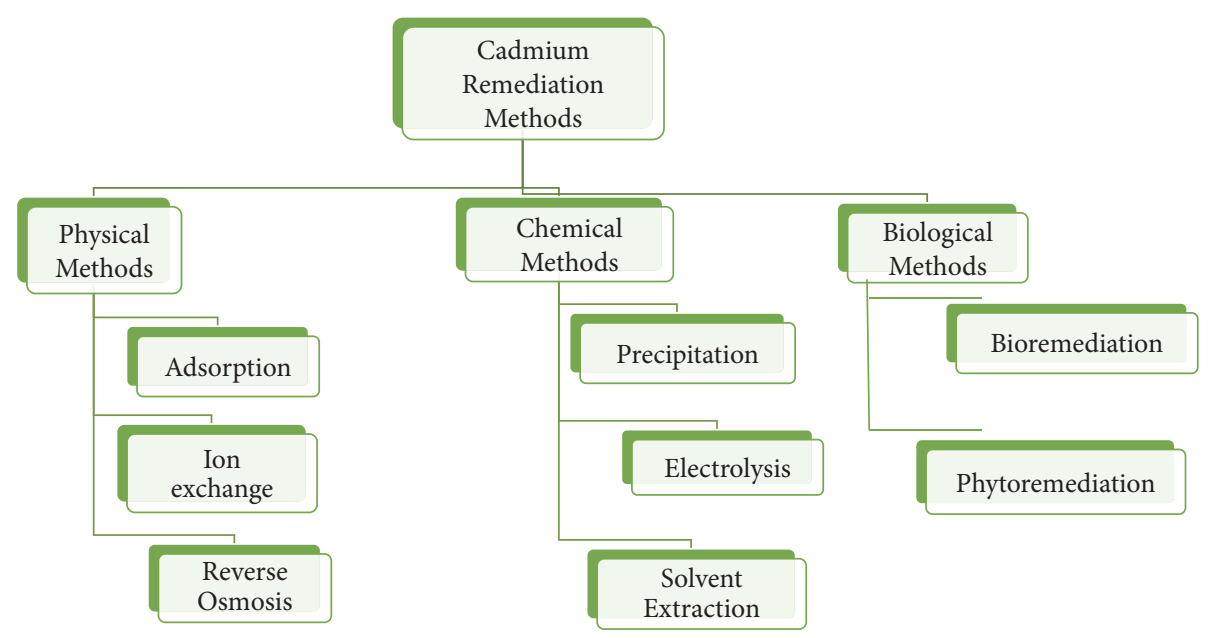

FIGURE 3: Flowchart of various methods used in Cd remediation.

rice husk, sugarcane bagasse, baker's yeast, etc., also helped in remediation of $\mathrm{Cd}$ [62-65]. Particular membranes were also detailed to adsorb $\mathrm{Cd}$ from its aqueous solution such as simple liquid membranes [66], liquid membranes formed on support [67], emulsifying membranes, etc. [68]. An electrodialysis cell which was divided into five compartments has been also used for the removal of $\mathrm{Cd}$ from wastewater [69]. Ion exchange method was also devised by using Lewatit TP 260 cationic exchanger resin [70]. But in literature, there is lack of knowledge for safe disposal and reuse of loaded adsorbents. Hence, applications of adsorbents have still not been possible commercially.

4.2. Chemical Methods. In chemical methods, firstly Schlage Lock Company demonstrated a method in which addition of Barium acetate coagulated Cd from electroplating industry effluents [71]. In a precipitation process, $\mathrm{Cd}^{2+}$ ions get removed by addition of $\mathrm{NaOH}$ [72], $\mathrm{Ca}(\mathrm{OH})_{2}$ and $\mathrm{Mg}(\mathrm{OH})_{2}$ [73]. Some researchers also proposed cementation processes for $\mathrm{Cd}^{2+}$ ions removal from its aqueous solution [74]. Through solvent extraction technique, $\mathrm{Cd}^{2+}$ ions get extracted by using various extracts such as Cyanex 301, aqueous nitrogen donor ligand [75] and phosphorus based extract [76]. In a stripping step of solvent extraction, a large amount of solvent gets utilized during the process which is the major cause for the failure. So, the adaptation of such methods should not be advisable where heavy metal removal concentration was very less.

4.3. Biological Methods. The bioremediation of Cd through microorganisms such as bacteria [77], fungi Aspergillus [78], yeast species [79], green algae Chlorella emersonii [80], brown algae Fucus vesiculosus [81], etc. was well reported in the literature. Microbial remediation of $\mathrm{Cd}$ provides an effective way to render Cd toxicity but the growth of microbes is possible only in optimum climate conditions. This parameter restricts the use of microbes for remediation purpose. In last decade, another biological technique which has been proposed for $\mathrm{Cd}$ removal from contaminated soil and water resources is phytoremediation which is well suited, cost-efficient, and eco-friendly in comparison to the above-mentioned techniques of remediation. The present review is intended to give information with respect to phytoremediation of $\mathrm{Cd}$.

\section{Phytoremediation of Cd in Contaminated Soil}

Remediation of Cd-contaminated soil is a substantial problem around the globe and it became more significant due to the transfer of $\mathrm{Cd}$ in higher trophic levels of food-chain. Cd hyperaccumulators are of particular interest because of their ability to tolerate and take up significant amounts of heavy metal from soils. Plants of different species have different capabilities to hyperaccumulate $\mathrm{Cd}$. As $\mathrm{Cd}$ has low affinities with soil ligands because of its mobile nature and hence, is easily extracted by roots and further transported to other aerial portions of the plant [82]. The factors responsible for remediation of $\mathrm{Cd}$ by plants are $\mathrm{pH}$, temperature, its concentration in media, and even concentration of elements other than Cd [83]. The phytoremediation mechanism for Cd removal in soil plants is represented in Figure 4.

In literature, it was mentioned that plant species which are known as $\mathrm{Cd}$ hyperaccumulator have the ability to accumulate $10^{5} \mathrm{mg} \mathrm{g}^{-1} \mathrm{Cd}$ in shoot dry weight [13]. A number of plant species have been reported for hyperaccumulation of Cd in soil as mentioned in Table 3.

Thlaspi caerulescens reported for Cd hyperaccumulation in the early 1990s. T. caerulescens showed much greater tolerance to Cd, with toxicity symptoms appearing at the 200 $\mu \mathrm{M}$ concentration. The translocation of $\mathrm{Cd}$ from solution to upper portions and its concentration of shoots of $T$. caerulescens was remarkably high [84]. The hairy root culture of $T$. caerulescens also showed remediation of $\mathrm{Cd}$ from its aqueous solution [116]. These results confirmed $T$. caerulescens as a hyperaccumulating plant for the remediation of Cd pollution. A. halleri and T. caerulescens were found to hyperaccumulate $\mathrm{Cd}$ along with $\mathrm{Zn}$ [117]. In case of $T$. caerulescens, most of $\mathrm{Cd}$ accumulated in roots while in case 


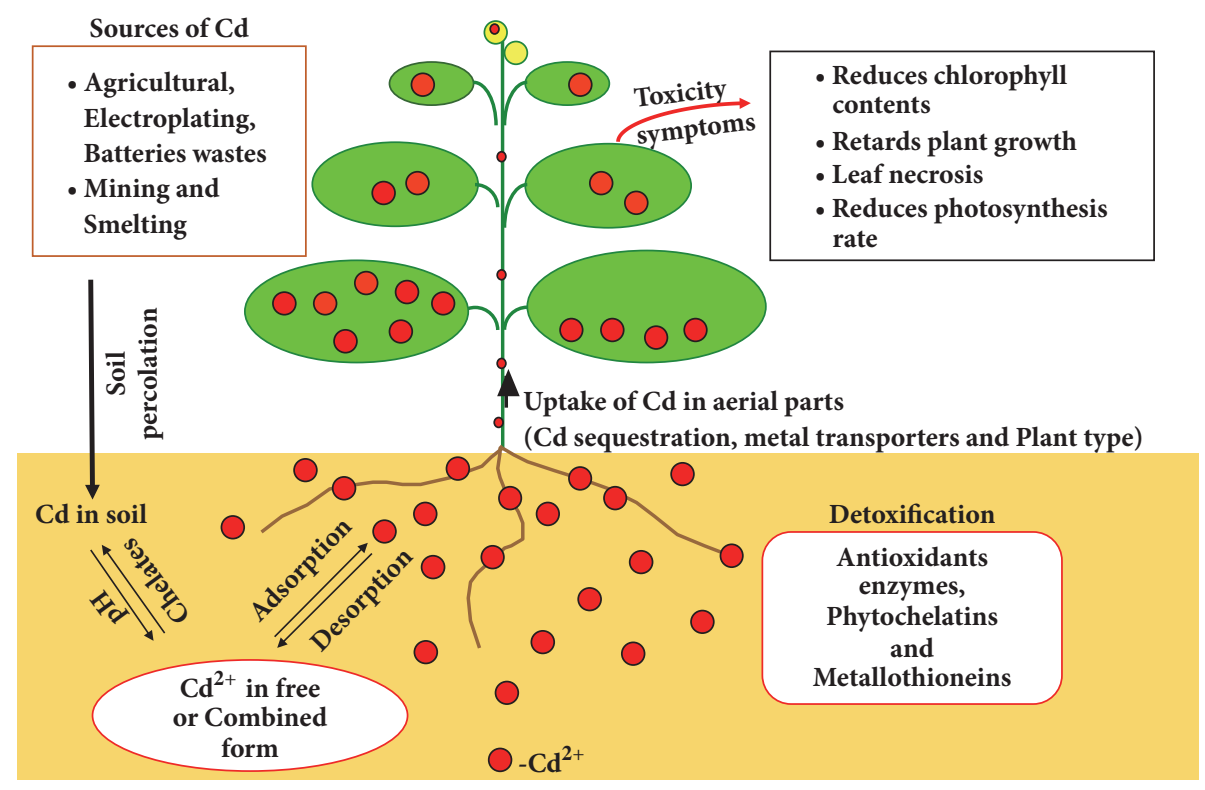

FIgUre 4: Phytoremediation mechanism of Cd adopted by soil plants.

of A. halleri, it was observed in leaf mesophyll [85]. But the problem found with these two plants $T$. caerulescens and $A$. halleri was that they were low-biomass plants and unable to bear an extensive range of environmental conditions. Consequently, Calamagrostis epigejos, Sedum species, Brassica species, and Solanum nigrum proposed as an alternative to T. caerulescens and A. halleri [118-125].

C. epigejos is a fast growing plant and able to tolerate extreme weather conditions and easily grown in poor sandy soils and marshy wetlands. Due to its high tolerance towards heavy metals, it was explored for Cd uptake and found low root to shoot transfer which infers that more ecological benefit of the plant in terms of phytostabilization can be achieved in comparison to phytoextraction [118].

In addition, $S$. nigrum have also been reported having the accumulation of high concentration of $\mathrm{Cd}$ along with $\mathrm{Cu}$ and Zn [96]. A study on EDTA effect on Cd uptake by S. nigrum was also reported. It was claimed that only moderate dose of EDTA $0.1 \mathrm{~g} \mathrm{Kg}^{-1}$ in soil effectively enhanced phytoextraction of Cd whereas high dose $0.5 \mathrm{~g} \mathrm{Kg}^{-1}$ adversely affected the growth of the plant and reduced biomass which results into reducing the effectiveness of phytoremediation method [119]. In a further study, the flowering stage potential of $S$. nigrum has been explored [120]. Thus, all these studies revealed that S. nigrum considerably accumulates a great amount of $\mathrm{Cd}$ and assists in controlling pollution in Cd-contaminated soils.

Another plant Sedum alfredii also showed a substantial potential for $\mathrm{Cd}$ remediation. In this study, it was shown that the amount of $\mathrm{Cd}$ gets enhanced on exposure to $\mathrm{Zn}$ concentrations [92]. The amount of both metals gets increased in leaves and stems with increase in concentration of $\mathrm{Cd}$ and $\mathrm{Zn}$. This result established that $S$. alfredii works as hyperaccumulator of both the metals, $\mathrm{Cd}$ as well as $\mathrm{Zn}$. The amendments such as humic acid and compost in soil with the DC current supply enhanced Cd extraction two- three folds by $S$. alfredii [121]. Another species S. plumbizincicola also reported to enhance $\mathrm{Cd}$ and $\mathrm{Zn}$ concentration on addition of EDTA by reducing mobility of ions in contaminated soil [122].

The large sized Brassica juncea (Indian mustard) was also found to phytoextract comparable amount of $\mathrm{Cd}$ as $T$. caerulescens. B. juncea plants have been found to tolerate inordinate $\mathrm{Cd}$ stress as compared to a Cd-sensitive species [123]. Another species of Brassica, B. napus, was found to be more stable on exposure of $\mathrm{Cd}$ as lipid changes were observed in cell membranes of $B$. napus on direct exposure to metal [124]. B. pekinensis which is also called Chinese cabbage was also explored for $\mathrm{Cd}$ extraction from soil and its six different varieties were found to extract a significant amount of $\mathrm{Cd}$ [125].

Researches were also conducted in hydroponic systems to explore more efficient soil plants for $\mathrm{Cd}$ remediation. Experiments were conducted in soil as well as in hydroponic system to explore the phytoremediation potential of Arundo donax. The authors concluded that a significant and better uptake of $\mathrm{Cd}$ was observed in the hydroponic system as compared to soil cultures as Bio Concentration Factor (BCF) and Translocation Factor (TF) were more than 1 but on high exposure of $\mathrm{Cd}$; antioxidant stress was shown by the plant [126]. Cd hyperaccumulation also reported in the bulb, shoot, and root of $A$. sativum (garlic) grown in hydroponic system and studies proved the capability of garlic to extract $\mathrm{Cd}$ from its solution and transport and store the same into various parts of garlic. With concentration increase of $\mathrm{Cd}^{2+}$, the amount of $\mathrm{Cd}$ in garlic roots gets enhanced. It has been found by investigators that the plant was able to extract $\mathrm{Cd}$ about 1826 times more than the control but a very limited quantity of Cd gets aggregated in bulbs and shoots of garlic [20]. Currently, Bidens pilosa was identified as Cd hyperaccumulator which accumulated $405.91 \mathrm{mg} \mathrm{kg}^{-1}$ and $1651.68 \mathrm{mg} \mathrm{kg}^{-1}$ in its 
TABLE 3: Cd hyperaccumulators reported for phytoremediation in soil.

\begin{tabular}{|c|c|c|c|}
\hline Plant species & Cd Concentration $\left(\mathrm{mg} \mathrm{kg}^{-1}\right)$ & Hyperaccumulating portion & Reference \\
\hline Thlaspi caerulescens & 1140 & Shoots & {$[84]$} \\
\hline \multirow{2}{*}{ Arabidopsis halleri } & 281 & Leaves & [85] \\
\hline & 1000 & Shoots & [86] \\
\hline Brassica napus & $11.94,263$ & Stems, Leaves & [87] \\
\hline Arabis gemmifera & 5600,6643 & Leaves, Shoots & {$[88]$} \\
\hline Arabis paniculata & 1662 & Leaves & [89] \\
\hline Viola boashanensis & 1168 & Shoots & {$[90]$} \\
\hline Salsola kali & 2075 & Stems & [91] \\
\hline Vetiver zizanioides & 0.33 & Leaves & {$[18]$} \\
\hline Sedum alfredii & 9000 & Leaves & {$[92]$} \\
\hline Rorippa globosa & 150 & Leaves & [93] \\
\hline Chromolaena odorata & 102 & Shoots & {$[94]$} \\
\hline Iris lactea & 529 & Shoots & [95] \\
\hline Solanum nigrum & 125 & Leaves & [96] \\
\hline \multirow{2}{*}{ Phytolacca americana } & 10,700 & Leaves & [97] \\
\hline & 2840 & Stems & {$[98]$} \\
\hline \multirow{2}{*}{ Bidens pilosa } & $108-376,144-400,27.9-101$ & Stem, Leaves, Seeds & [99] \\
\hline & 405.91 & Shoots & [100] \\
\hline Atriplex halimus & 218 & Shoots & [101] \\
\hline Amaranthus mangostanus & 260 & Shoots & [102] \\
\hline Amaranthus hybridus & 242 & Shoots & [103] \\
\hline Picris divaricata & 1109 & Shoots & [104] \\
\hline Gynura pseudochina & 457 & Shoots & {$[105]$} \\
\hline Lonicera japonica & 345 and 286 & Stems and Shoots & {$[106]$} \\
\hline Lycopersicon esculentum & 130 & Shoots & {$[107]$} \\
\hline Arthrocnemum macrostachyum & 70 & Shoots & [108] \\
\hline Prosopis laevigata & 8176 & Shoots & [109] \\
\hline Carthamus tinctorius & 277 & Leaves & {$[110]$} \\
\hline Helianthus tuberosus & $>100$ & Stems and Leaves & [111] \\
\hline Siegesbeckia orientalis & 193 & Shoots & [112] \\
\hline Youngia erythrocarpa & 100 & Shoots & [113] \\
\hline Macleaya cordata & 393 & Plant & [114] \\
\hline turnip landraces & $52.94-146.95$ & Shoots & [115] \\
\hline
\end{tabular}

shoots when grown in soil and nutrient solution, respectively. These results implied that concentration of $\mathrm{Cd}$ accumulated by Bidens pilosa grown in nutrient solution was much more than plants grown in soil. This study also revealed that the $\mathrm{Cd}$ translocation and accumulation in plant was controlled by $\mathrm{K}^{+}$relative permeability ratio, MDA (Malondialdehyde) levels and conductivity of ions [100].

Recently, Coronopus didymus, and Abelmoschus manihot were among newly discovered plants for the hyperaccumulation of Cd in hydroponics. In C. didymus, TF reported to be higher than BCF [127]. In A. manihot, BCF values exceeded the reference value and TF values were also found to be greater than 1 on Cd treatment at $15-60 \mathrm{mg} \mathrm{kg}^{-1}$ [128]. It has been also reported in both the studies that superoxide anion amount, $\mathrm{H}_{2} \mathrm{O}_{2}$ content and antioxidative activities in roots and shoots get enhanced on exposure of a high dose of $\mathrm{Cd}$ which helps in the detoxification process $[127,128]$. Hence, $C$. didymus and A. manihot can be used as Cd hyperaccumulator to remediate $\mathrm{Cd}$ from actual field sites.

\section{Phytoremediation of $\mathrm{Cd}$ in Wastewater}

The waste waters from industries are usually discharged into water bodies and aquatic macrophytes provide a way out for removal of heavy metals present in water. Eichhornia crassipes, Alternanthera sessilis, Ceratophyllum demersum, Azolla pinnata, Chara coralline, Hygrorrhiza aristata, Hydrodictyon reticulatum, Hydrocotyle umbellate, Lemna minor, Salvinia, Pistia, Spirodela polyrhiza, Vallisneria spiralis, etc. were some species of aquatic plants reported for heavy metal remediation from water bodies [129].

Phytoremediation experiments with Eichhornia crassipes which is commonly known as water hyacinth were well documented for the Cd removal along with $\mathrm{Zn}$ and $\mathrm{Cr}[130,131]$. 
Initially, Woverlton and McDonald reported the E. crassipes potential for heavy metal remediation in aquatic media. According to reports, E. crassipes was able to accumulate a substantial amount of Cd 371 and $6,103 \mathrm{mg} \mathrm{kg}^{-1}$ in shoots and roots (dry weight), respectively [32]. But in another study, it was observed that high concentration $\mathrm{Cd}\left(100 \mathrm{mg} \mathrm{L}^{-1}\right)$ with other metals results in lesser amount of $\mathrm{Cd}$ in the aerial parts rather than in shoots [132]. Thus, from the perspective of phytoremediation, E. crassipes becomes a favorable choice among various macrophytes for remediation of wastewater effluent [133].

An interesting observation is reported by another author in case of Hydrilla verticillata. A submerged aquatic plant, $H$. verticillata, showed maximum absorption of $\mathrm{Cd}$ at the growth temperature $\left(15-25^{\circ} \mathrm{C}\right)$, but in between $5 \mathrm{pm}$ to $5 \mathrm{am}$ it released some of its absorbed metal content in solution which, otherwise, showed a decline during the daytime [134]. Azolla pinnata, another floating macrophyte, was found to be more effective in comparison to E. crassipes. The BCF for Cd in roots of Azolla was reported as 24,000 which was quite high [135]. At very low concentrations, A. pinnata and L. minor were found to be very effective in Cd remediation $[19,136,137]$. Pistia stratiotes with long feathery roots was able to bear $20 \mathrm{mg} \mathrm{L}^{-1} \mathrm{Cd}$ and plant growth got declined by increasing $\mathrm{Cd}$ concentration [138]. In comparison with Salvinia herzegoii, it accumulate a high level of Cd [139]. But another species of Salvinia, S. minima was reported as considered as a Cd hyperaccumulator. Hyperaccumulation of S. minima has been attributed to the increased specific surface area of roots with hydroxyl and carboxyl groups [140].

Another aquatic macrophytes such as Potamogeton natans, Myriophyllum aquaticum, Wolffia globosa, and Typha also showed the high accumulation of Cd [141-143]. Thus, the potential of aquatic macrophytes was studied very extensively for removal of $\mathrm{Cd}$. The potential of these aquatic macrophytes can be used to remediate $\mathrm{Cd}$ from contaminated water streams in an eco-friendly manner.

\section{Field Studies on Cd Remediation}

All above-mentioned studies demonstrated the ability of hyperaccumulators of $\mathrm{Cd}$ in contaminated soil and water. In spite of this, a very few field trials were reported for phytoremediation of Cd metal. A case study was done at the El-Gabal El-Asfar region (GA region) of Cairo to investigate the role of the $S$. nigrum as metal hyperaccumulator in remediation of agricultural soils, which had been irrigated with sewage water and had got contaminated with heavy metals. A relative ratio of soluble sugars, alkaloid, phenolic compounds, proteins, and amino acids such as proline, glycine, etc. increased on enhancing the concentration of metal in the root, leaves, and stem of S. nigrum [144].

Another case study was carried out in agricultural fields of Mae Sot District, Thailand. These fields of Mae Sot were highly contaminated with $\mathrm{Cd}$ metal and it became a health issue of Thai people. Five different plant species Chromolaena odorata, Gynura pseudochina, Conyza sumatrensis, Nicotiana tabacum and Crassocephalum crepidioides developed and out of these except Chromolaena odorata, all other four species successful in removing Cd from the soil of agricultural fields [145]. Recently, it has been found that Napier grass reduced Cd concentration of soil by $4.6 \%$ in sites of Kyushu (Japan) where field trials were done in Cd-contaminated soil twice a year. There was no effect on yield of the crop but amazingly concentration of $\mathrm{Cd}$ from soil got increased at the second time cultivation [146]. In another study, three species of Armeria plant were explored for phytoremediation potential of the heavy metal in the minning area of Serbia. Three tested Armeria species were grown in eight different areas and none of the species showed shoot hyperaccumulation potential for any of the tested heavy metals. Armeria plant signified as root accumulators by authors due to their high bioconcentration factor $134(\mathrm{Zn}), 148(\mathrm{Cr})$, and $9(\mathrm{Cd})$ in their roots [147].

Palutoglu et al. explored the phytoremediation potential of native species of Turkey in the Gümüsköy mining area which is known for the largest silver deposit. In this area, the concentration of $\mathrm{Cd}$ in contaminated soil was observed to be high $82.8 \mathrm{mg} \mathrm{kg}^{-1}$. The native plants under study showed $55.4 \mathrm{mg} \mathrm{kg}^{-1} \mathrm{Cd}$ accumulation in their root and $43.5 \mathrm{mg} \mathrm{kg}^{-1}$ shoot, respectively. The plant species Carduus nutans and Phlomis were found to be the most effective out of eleven native tested species [148]. In a recent field study with Ganges ecotype of T. caerulescen, the role of soil geochemical factors and plant-soil interactions for Cd uptake were highlighted by hyperaccumulating plants [149]. This points towards the importance of the need for understanding site-specificity containing metal and soil geochemical properties in consideration before phytoremediation of actual field sites.

\section{Uptake Mechanism and Detoxification of Cd in Plants}

A comprehensive study of $\mathrm{Cd}$ detoxification and accumulation mechanism in plants was done by different researchers. Cd hyperaccumulating plants adopted various cellular and molecular mechanisms for their detoxification. Hyperaccumulation of Cd basically involves three processes, namely adsorption, transportation, and translocation. Adsorption of $\mathrm{Cd}$ primarily occurs through roots of the plant. Some factors like $\mathrm{pH}$, humic acid, and medium are mainly responsible for effective absorption of $\mathrm{Cd}^{2+}$ [150]. In roots, the tissue in the root tip which adsorbed cations from the source. In the presence of root hairs, the efficiency of adsorption processes gets enhanced as the area of contact gets increased which accelerate the pace of Cd ion adsorption via root tissues [151]. In fact, root hairs were considered as the most influential part of root for adsorption process and the adsorption of most of the Cd from the soil takes place through cells of root hairs.

Cd entry into the plant through root cells mainly takes place through the exchange of ions, the release of organic acids, chelating to metal ions and sequestration to root cells. The transportation of $\mathrm{Cd}$ depends on medium, metal and plant properties. Song et al. suggested that transportation of $\mathrm{Cd}$ can take place through apoplastic and symplastic pathways [152]. A diagrammatic representation of these pathways was shown in Figure 5. A prompt exchange of $\mathrm{Cd}^{2+}$ ions takes place with $\mathrm{H}^{+}$in plasma membranes of root cells 


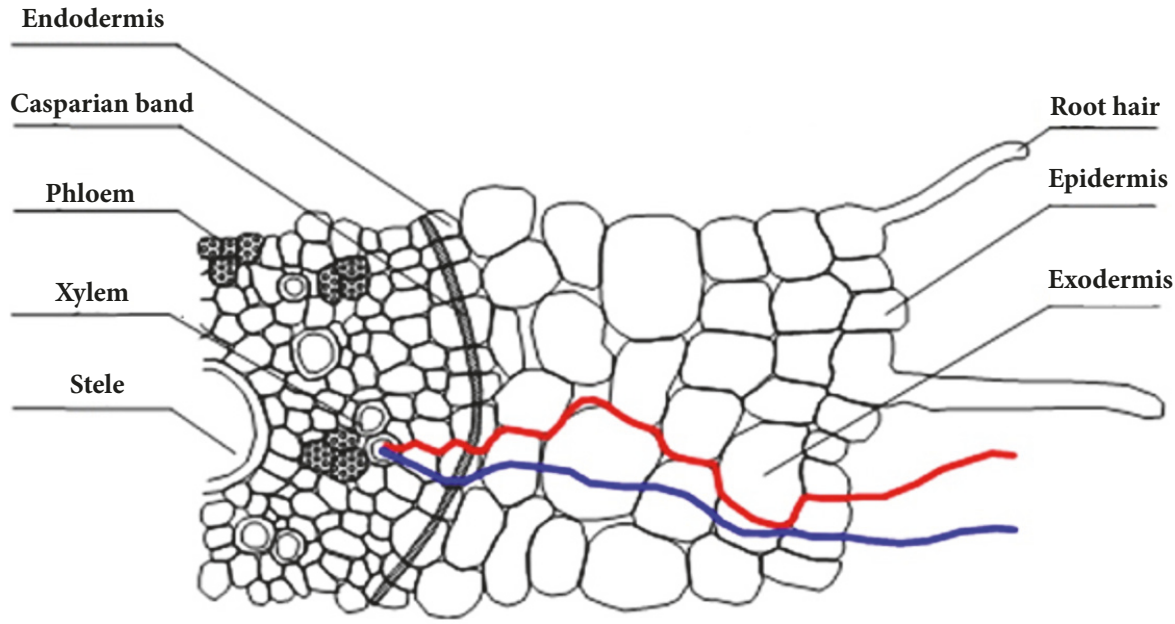

(a) Root cross section

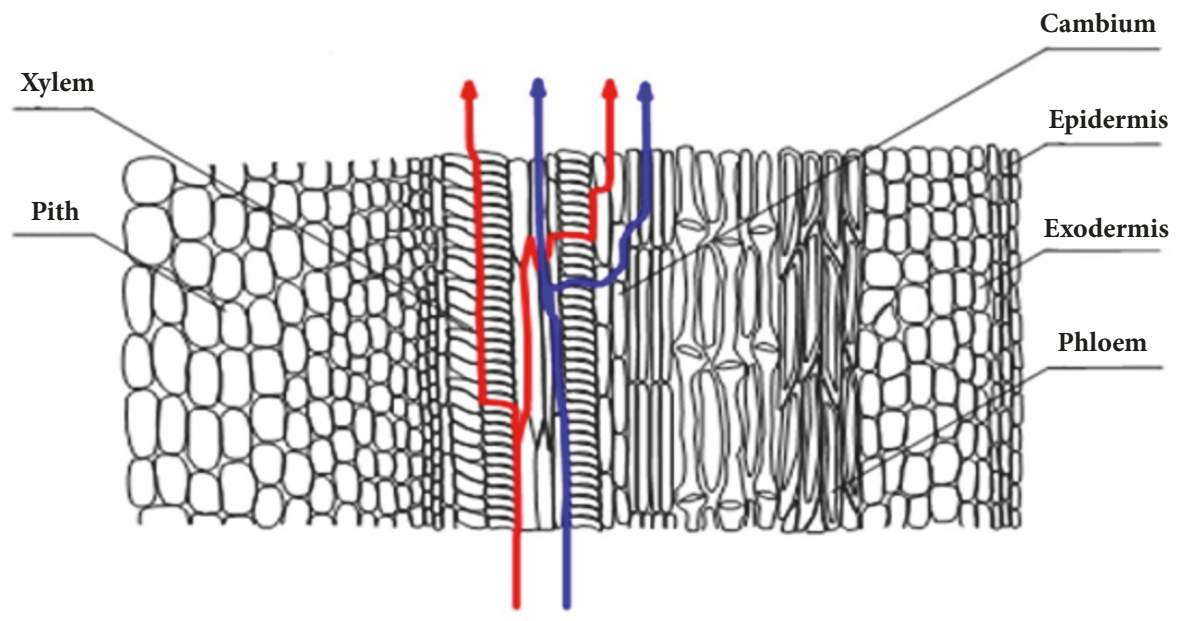

(b) Stem cross section

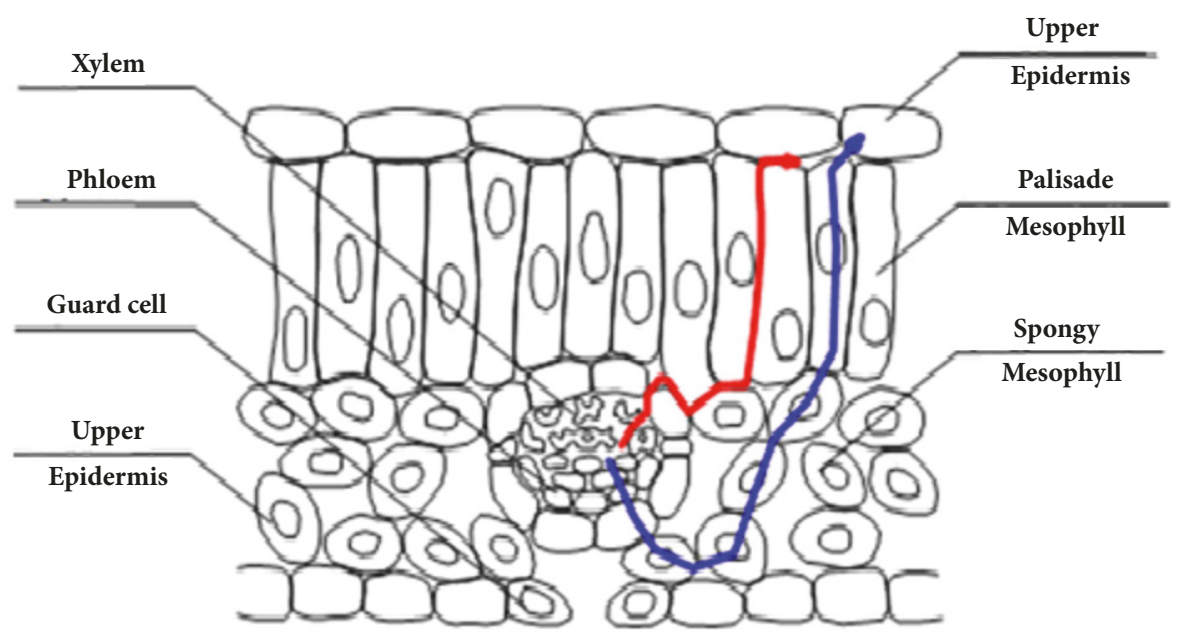

(c) Leaf cross section

FIGURE 5: Diagram of apoplastic and symplastic pathways of Cd transport. The red and blue line show the apoplastic and symplastic pathway, respectively (source: Song et al. reprinted with permission). 
and through apoplast pathway, $\mathrm{Cd}^{2+}$ ions get adsorbed [153]. Another pathway for Cd entry in plant cells was through the symplast pathway. In this pathway, Cd gets combined with transporter proteins and then is passed via ion channels and enters into the epidermis layer of root cells [152]. But the relationship between the apoplastic and symplastic pathway of Cd transportation is not reported yet. In some cases, it has also been observed that plant roots also released chelates which bind with $\mathrm{Cd}^{2+}$ to form metal-ligand complexes about quick adsorption. The order for $\mathrm{Cd}$ accumulation in plants was found to be: roots $>$ stems $>$ leaves $>$ fruits $>$ seeds.

The mechanism of accumulation and antioxidative metabolism to tolerate $\mathrm{Cd}$ by hairy roots of $T$. caerulescens revealed that $\mathrm{Cd}$ metal-induced stress in tissues [116]. The factors like $\mathrm{pH}$ and $\mathrm{H}^{+}$-ATPase inhibitor enzyme affected $\mathrm{Cd}$ hyperaccumulation. The author also studied the $\mathrm{Cd}$ distribution in mesophyll protoplast of leaf cells in both the hyperaccumulating plants, namely, $T$. caerulescens and $A$. halleri. It was also suggested that a regulation mechanism existed on leaf mesophyll protoplasts in plasma membranes. Preexposure of $\mathrm{Cd}$ to the plant showed an exponential elevation in its concentration in leaf mesophyll protoplast of T. caerulescens, but a decline in the quantity of Cd in A. halleri [117]. From these results, it can be specified that the regulation mechanism for $\mathrm{Cd}$ transportation in plants is different for each plant. According to another study on A. thaliana for the remediation of $\mathrm{Cd}$ with the help of yeast protein, the yeast protein detached $\mathrm{Cd}$ through its extraction from source and transportation into vacuole of cells [154].

Scanning Electron Microscopy (SEM) and energy dispersive X-ray (EDX) microanalysis were also used by the researcher to analyse plant tissues of the lower epidermis, mesophyll protoplasts, and cell walls. SEM and EDX studies confirmed the Cd presence inside the epidermal cells as well as in the cell walls of plant tissue. Cd was found both in the large as well as small epidermal cells and not only in the cell walls but also in the cytoplasm of cells. These results concluded that metal is stored not only in one part of the cell but also gets distributed in other compartments of leaf mesophyll. It was also concluded by the author that in epidermal cells metabolic activities are almost negligible and $\mathrm{Cd}$ is mainly stored in these less active cells and hence does not interfere with activities of other cells [155].

Cd detoxification in hyperaccumulating plants occurred either through vacuole sequestration or by binding through cysteine-rich proteins. Plant sequestration of $\mathrm{Cd}^{2+}$ into the vacuole and removal of $\mathrm{Cd}^{2+}$ from the cytosol of the cell were also reported [156]. As vacuole of the cell is considered for detoxification process and a large number of metabolites get stored in it to detoxify the cytosol [157]. Vacuole sequestration of $\mathrm{Cd}$ has been reported to occur mainly through transporters $\mathrm{Ca}^{2+}$ exchangers (CAXs) and heavy metal ATP ase (HMAs) [158]. In Arabidopsis plant, HMAs is responsible for sequestering $\mathrm{Cd}$ in the root and controls $\mathrm{Cd}$ transfer from root to the aerial parts of plant [159]. Plants such as $S$. alfredii and $N$. caerulescens have potential to store a large amount of $\mathrm{Cd}$ in the aerial parts which reported to possess some high expression genes which play an important part in the accumulation of Cd [160]. The HMAs from both plants possessed high substrate specificity for Cd over other heavy metals like $\mathrm{Zn}, \mathrm{Pb}$, and $\mathrm{Co}[160,161]$. However, the substrate specificity of HMAs mechanisms of Cd hyperaccumulation has yet to be explored.

Another detoxification Cd mechanism involved two types of cysteine-rich peptides known as Phytochelatins (PCs) and Metallothioneins (MTs) [162]. Being a thiol reactive metal, $\mathrm{Cd}$ bound with these peptides gets detoxified. MTs are low molecular mass peptides which amalgamated on ribosomes. Plants with complex MTs genes are able to tolerate the toxicity of metal ions and aid transportation the ions as well. On exposure to Cd, MTs are also helpful in the shielding of chloroplasts of guard cell from degradation [163]. When detoxification of Cd occurs through PCs then MT bind Cd as such in the cytoplasm and the same was not tucked away into the vacuole. PCs were also found as Cd-binding peptides through carboxyl and the sulfhydryl residues in presence of enzyme phytochelatin synthase (PCS) and Cd thought to be acting as cofactor for glutathione to PCs conversions [163]. Also, various types of reactive oxygen species (ROS) such as superoxide anion $\mathrm{O}^{2-}$ and $\mathrm{H}_{2} \mathrm{O}_{2}$ and antioxidative enzymes induced detoxification process of $\mathrm{Cd}$ at high $\mathrm{Cd}$ concentrations $[127,128]$. A schematic representation of $\mathrm{Cd}$ detoxification in plant cell is given in Figure 6. Recently, genome-wide studies have been also used to explore detoxification mechanisms in $\mathrm{Cd}$ metal hyperaccumulators $T$. caerulescens and Brassica chinensis [161, 164] but still, there is a lot of scope of research.

\section{Conclusion}

Cd removal through phytoremediation emerges as a sustainable technology for contaminated soil as well as wastewater. Phytoremediation has high performance results when compared with other conventional technologies for Cd metal removal. The plant species from wide group of families have been recognized as Cd hyperaccumulators in last two decades. Different hyperaccumulating plants have varied abilities to accumulate, sequester, and detoxify Cd. Research studies are in headway to elucidate the various mechanism adopted by different plants to combat the toxicity of $\mathrm{Cd}$ at physiological and molecular level. But, the genetic level control of Cd detoxification in plants is not yet identified. Despite the lot of developments made in field of Cd phytoremediation from contaminated soil and water, only a limited number of research studies have taken place in field conditions. Hence, there is an urgent need for research on improving experimental design of phytoremediation relevant to $\mathrm{Cd}$ concentration in soil and water. In addition, the methods for the disposal of $\mathrm{Cd}$-enriched biomass need to be further explored. Moreover, for practical approach, there is urgent need of integration of established method with phytoremediation technique to provide an innovative solution for $\mathrm{Cd}$ removal from soil and water.

\section{Disclosure}

The manuscript has been prepared by the consent of coauthor. 


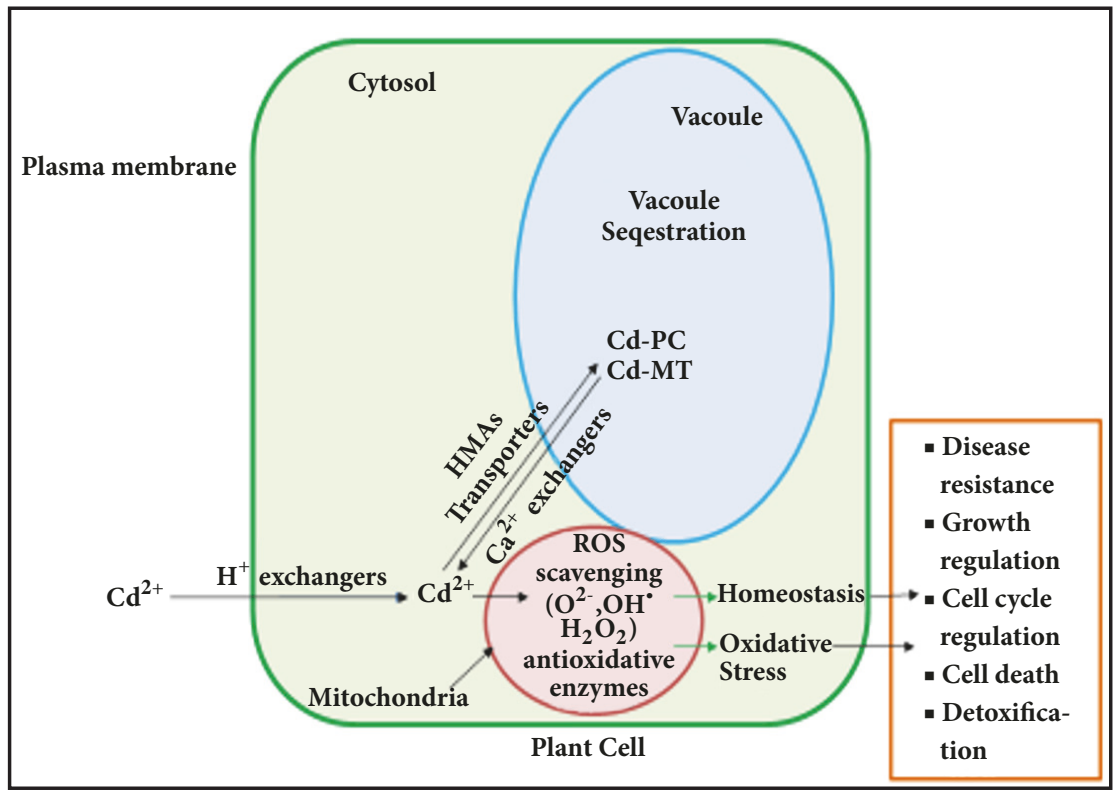

FIGURE 6: Schematic representation of Cd detoxification in plant cell (heavy metal ATP ases (HMAs), phytochelatins (PC), metallothioneins (MT), and reactive oxygen species (ROS)).

\section{Conflicts of Interest}

The authors would like to declare that there are no conflicts of interest for publication of this article.

\section{Acknowledgments}

The authors are grateful to the Taylor \& Francis for providing permission of reprint the figure.

\section{References}

[1] P. Vara, M. Narasimha, and H. M. de Oliveira Freitas, "Metal hyperaccumulation in plants: biodiversity prospecting for phytoremediation technology," Electronic Journal of Biotechnology, vol. 6, no. 3, pp. 285-321, 2003.

[2] F. X. Han, A. Banin, Y. Su et al., "Industrial age anthropogenic inputs of heavy metals into the pedosphere," Naturwissenschaften, vol. 89, no. 11, pp. 497-504, 2002.

[3] L. Santona, P. Castaldi, and P. Melis, "Evaluation of the interaction mechanisms between red muds and heavy metals," Journal of Hazardous Materials, vol. 136, no. 2, pp. 324-329, 2006.

[4] T. Fletcher, "Neighborhood change at Love Canal: contamination, evacuation and resettlement," Land Use Policy, vol. 19, no. 4, pp. 311-323, 2002.

[5] R. R. Hinchman, M. C. Negri, and E. G. Gatliff, "Phytoremediation: using green plants to clean up contaminated soil, groundwater and wastewater," in Proceedings of the International Topical Meeting on Nuclear and Hazardous Waste ManagementSpectrum, vol. 96, pp. 1-13, 1996.

[6] R. L. Chaney, M. Malik, Y. M. Li et al., "Phytoremediation of soil metals," Current Opinion in Biotechnology, vol. 8, no. 3, pp. 279-284, 1997.

[7] I. Raskin, R. D. Smith, and D. E. Salt, "Phytoremediation of metals: Using plants to remove pollutants from the environment," Current Opinion in Biotechnology, vol. 8, no. 2, pp. 221-226, 1997.
[8] A. Rew, "Phytoremediation: an environmentally sound technology for pollution prevention, control and remediation in developing countries," Educational Research and Reviews, vol. 2, no. 7, pp. 151-156, 2007.

[9] H. G. Schlegel, J. -. Cosson, and A. J. M. Baker, "Nickel-hyperaccumulating Plants Provide a Niche for Nickel-resistant Bacteria," Botanica Acta, vol. 104, no. 1, pp. 18-25, 1991.

[10] R. R. Brooks, J. Lee, R. D. Reeves, and T. Jaffre, "Detection of nickeliferous rocks by analysis of herbarium specimens of indicator plants," Journal of Geochemical Exploration, vol. 7, pp. 49-57, 1977.

[11] N. Kirkwood, "Here come the hyperaccumulators," Harvard Design Magazine Fall/Winter, pp. 1-4, 2002.

[12] R. B. Meagher, "Phytoremediation of toxic elemental and organic pollutants," Current Opinion in Plant Biology, vol. 3, no. 2, pp. 153-162, 2000.

[13] A. Baker and R. Brooks, "Terrestrial higher plants which hyperaccumulate metallic elements. A review of their distribution, ecology and phytochemistry," Biorecovery, vol. 1, no. 2, pp. 81126, 1989.

[14] P. K. Padmavathiamma and L. Y. Li, "Phytoremediation technology: hyper-accumulation metals in plants," Water, Air, \& Soil Pollution, vol. 184, no. 1-4, pp. 105-126, 2007.

[15] Q.-E. Xie, X.-L. Yan, X.-Y. Liao, and X. Li, “The arsenic hyperaccumulator fern Pteris vittata L.," Environmental Science \& Technology, vol. 43, no. 22, pp. 8488-8495, 2009.

[16] S. B. Jonnalagadda and G. Nenzou, "Studies on arsenic rich mine dumps. II. The heavy element uptake by vegetation," Journal of Environmental Science and Health, Part A: Toxic/Hazardous Substances and Environmental Engineering, vol. 32, no. 2, pp. 455-464, 1997.

[17] M. Murakami, N. Ae, and S. Ishikawa, "Phytoextraction of cadmium by rice (Oryza sativa L.), soybean (Glycine max (L.) Merr.), and maize (Zea mays L.)," Environmental Pollution, vol. 145, no. 1, pp. 96-103, 2007. 
[18] H.-Y. Lai and Z.-S. Chen, "Effects of EDTA on solubility of cadmium, zinc, and lead and their uptake by rainbow pink and vetiver grass," Chemosphere, vol. 55, no. 3, pp. 421-430, 2004.

[19] W. Hou, X. Chen, G. Song, Q. Wang, and C. Chi Chang, "Effects of copper and cadmium on heavy metal polluted waterbody restoration by duckweed (Lemna minor)," Plant Physiology and Biochemistry, vol. 45, no. 1, pp. 62-69, 2007.

[20] W. Jiang, D. Liu, and W. Hou, "Hyperaccumulation of cadm ium by roots, bulbs and shoots of garlic," Bioresource Technology, vol. 76, no. 1, pp. 9-13, 2001.

[21] X.-H. Zhang, J. Liu, H.-T. Huang, J. Chen, Y.-N. Zhu, and D.Q. Wang, "Chromium accumulation by the hyperaccumulator plant Leersia hexandra Swartz," Chemosphere, vol. 67, no. 6, pp. 1138-1143, 2007.

[22] H. Diwan, A. Ahmad, and M. Iqbal, "Genotypic variation in the phytoremediation potential of indian mustard for chromium," Journal of Environmental Management, vol. 41, no. 5, pp. 734741, 2008.

[23] E. Moreno-Jiménez, R. Gamarra, R. O. Carpena-Ruiz, R. Millán, J. M. Peñalosa, and E. Esteban, "Mercury bioaccumulation and phytotoxicity in two wild plant species of Almadén area," Chemosphere, vol. 63, no. 11, pp. 1969-1973, 2006.

[24] K. Skinner, N. Wright, and E. Porter-Goff, "Mercury uptake and accumulation by four species of aquatic plants," Environmental Pollution, vol. 145, no. 1, pp. 234-237, 2007.

[25] A. C. Singer, T. Bell, C. A. Heywood, J. A. C. Smith, and I. P. Thompson, "Phytoremediation of mixed-contaminated soil using the hyperaccumulator plant Alyssum lesbiacum: evidence of histidine as a measure of phytoextractable nickel," Environmental Pollution, vol. 147, no. 1, pp. 74-82, 2007.

[26] Q. Chen and J. W. C. Wong, "Growth of Agropyron elongatum in a simulated nickel contaminated soil with lime stabilization," Science of the Total Environment, vol. 366, no. 2-3, pp. 448-455, 2006.

[27] N. R. Axtell, S. P. K. Sternberg, and K. Claussen, "Lead and nickel removal using Microspora and Lemna minor," Bioresource Technology, vol. 89, no. 1, pp. 41-48, 2003.

[28] M. Del Río-Celestino, R. Font, R. Moreno-Rojas, and A. De Haro-Bailón, "Uptake of lead and zinc by wild plants growing on contaminated soils," Industrial Crops and Products, vol. 24, no. 3, pp. 230-237, 2006.

[29] P. Rotkittikhun, R. Chaiyarat, M. Kruatrachue, P. Pokethitiyook, and A. J. M. Baker, "Growth and lead accumulation by the grasses Vetiveria zizanioides and Thysanolaena maxima in leadcontaminated soil amended with pig manure and fertilizer: A glasshouse study," Chemosphere, vol. 66, no. 1, pp. 45-53, 2007.

[30] K. Chandra Sekhar, C. T. Kamala, N. S. Chary, A. R. K. Sastry, T. Nageswara Rao, and M. Vairamani, "Removal of lead from aqueous solutions using an immobilized biomaterial derived from a plant biomass," Journal of Hazardous Materials, vol. 108, no. 1-2, pp. 111-117, 2004.

[31] D. A. Moreno, G. Víllora, M. T. Soriano, N. Castilla, and L. Romero, "Sulfur, chromium, and selenium accumulated in Chinese cabbage under direct covers," Journal of Environmental Management, vol. 74, no. 1, pp. 89-96, 2005.

[32] Y. L. Zhu, A. M. Zayed, J.-H. Qian, M. De Souza, and N. Terry, "Phytoaccumulation of trace elements by wetland plants: II. Water hyacinth," Journal of Environmental Quality, vol. 28, no. 1, pp. 339-344, 1999.

[33] G. S. Bañuelos, S. Zambrzuski, and B. Mackey, "Phytoextraction of selenium from soils irrigated with selenium-laden effluent," Plant and Soil, vol. 224, no. 2, pp. 251-258, 2000.
[34] H. Vandenhove and M. Van Hees, "Phytoextraction for cleanup of low-level uranium contaminated soil evaluated," Journal of Environmental Radioactivity, vol. 72, no. 1-2, pp. 41-45, 2004.

[35] V. Dushenkov, P. B. A. Nanda Kumar, H. Motto, and I. Raskin, "Rhizofiltration: the use of plants to remove heavy metals from aqueous streams," Environmental Science and Technology, vol. 29, no. 5, pp. 1239-1245, 1995.

[36] N. Sarwar, M. Imran, M. R. Shaheen et al., "Phytoremediation strategies for soils contaminated with heavy metals: Modifications and future perspectives," Chemosphere, vol. 171, pp. 710721, 2017.

[37] S. P. McGrath, in Phytoextraction for soil remediation: Plants that hyperaccumulate heavy metals, R. R. Brooks, Ed., pp. 109-128, CAB International, New York, NY, USA, 1998.

[38] M. I. Silva Gonzaga, J. A. G. Santos, and L. Q. Ma, "Arsenic chemistry in the rhizosphere of Pteris vittata L. and Nephrolepis exaltata L.," Environmental Pollution, vol. 143, no. 2, pp. 254260, 2006.

[39] F. Vera Tomé, P. Blanco Rodríguez, and J. C. Lozano, "Elimination of natural uranium and 226Ra from contaminated waters by rhizofiltration using Helianthus annuus L.," Science of the Total Environment, vol. 393, no. 2-3, pp. 351-357, 2008.

[40] S. Eapen and S. F. D'Souza, "Prospects of genetic engineering of plants for phytoremediation of toxic metals," Biotechnology Advances, vol. 23, no. 2, pp. 97-114, 2005.

[41] J. Barcel and C. Poschenrieder, "Phytoremediation: principles and perspectives," Contributions to Science, vol. 2, no. 3, pp. 333344, 2003.

[42] B. R. James, "Remediation-by-reduction strategies for chromate-contaminated soils," Environmental Geochemistry and Health, vol. 23, no. 3, pp. 175-179, 2001.

[43] W. R. Berti and S. D. Cunningham, in Phytostabilization of metals: Phytoremediation of toxic metals: using plants to cleanup the environment, pp. 71-88, John Wiley and Sons, Inc, New York, NY, USA, 2000.

[44] M. Ghosh and S. Singh, "A review on phytoremediation of heavy metals and utilization of it's by products," Asian Journal Energy and Environment, vol. 6, no. 4, p. 18, 2005.

[45] S. Dushenkov, "Trends in phytoremediation of radionuclides," Plant and Soil, vol. 249, no. 1, pp. 167-175, 2003.

[46] M. P. De Souza, E. A. H. Pilon-Smits, and N. Terry, in The physiology and biochemistry of selenium volatilization by plants: Phytoremediation of toxic metals: using plants to clean-up the environment, pp. 171-190, John Wiley and Sons, Inc, New York, NY, USA, 2000.

[47] "U.S. Environmental Protection Agency, Integrated Risk Information System (IRIS) on Cadmium," National Centre for Environmental Assessment, Office of Research and Development, Washington, DC, 1999.

[48] S. Satarug, S. H. Garrett, M. A. Sens, and D. A. Sens, "Cadmium, environmental exposure, and health outcomes," Ciencia \& Saúde Coletiva, vol. 16, no. 5, pp. 2587-2602, 2011.

[49] BIS (Bureau of Indian Standards), Indian standard for drinking water-specification, Drinking Water Sectional Committee, New Delhi, India, 2nd edition, 2012, IS 10500: 2012, FAD 25.

[50] NHMRC and NRMMC, "National Water Quality Management Strategy, National Health and Medical Research Council, National Resource Management Ministerial Council, Commonwealth of Australia, Canberra," pp. 6, 2011.

[51] WHO, Guidelines for drinking water quality, Recommendations WHO, Geneva, vol. 1, no. 2, p. 130. 
[52] Canadian or B.C. Health Act Safe Drinking Water Regulation BC Reg 230/92, \&amp; 390 Sch 120, 2001, Task Force of Canadian Council of Resource and Envir. Ministers Guidelines for Canadian Drinking Water Quality, 1996, Amend, Health Canada, 2006.

[53] J. A. Ryan, H. R. Pahren, and J. B. Lucas, "Controlling cadmium in the human food chain: A review and rationale based on health effects," Environmental Research, vol. 28, no. 2, pp. 251302, 1982.

[54] G. F. Nordberg, "Current issues in low-dose cadmium toxicology: nephrotoxicity and carcinogenicity," Enviromental Science, vol. 4, no. 3, pp. 133-147, 1996.

[55] U. Forstner and G. T. W. Wittmann, Metal Pollution in The Aquatic Environment, Springer Science and Business Media, 2012.

[56] D. E. Salt, M. Blaylock, V. Dushenkov et al., "Phytoremediation: a novel strategy for the removal of toxic metals from the environment using plants," Nature Biotechnology, vol. 13, no. 5, pp. 468-474, 1995.

[57] A. Hegedüs, S. Erdei, and G. Horváth, "Comparative studies of $\mathrm{H} 2 \mathrm{O} 2$ detoxifying enzymes in green and greening barley seedlings under cadmium stress," Journal of Plant Sciences, vol. 160, no. 6, pp. 1085-1093, 2001.

[58] C. D. Foy, R. L. Chaney, and M. C. White, "The physiology of metal toxicity in plants," Annual Review of Plant Biology, vol. 29, no. 1, pp. 511-566, 1978.

[59] T. K. Sen and M. V. Sarzali, "Adsorption of cadmium metal ion $\left(\mathrm{Cd}^{2+}\right)$ from its aqueous solution by aluminium oxide and kaolin: a kinetic and equilibrium study," Journal of Environmental Research and Development, vol. 3, pp. 220-227, 2008.

[60] Y. Orhan and H. Büyükgüngör, "The removal of heavy metals by using agricultural wastes," Water Science \& Technology, vol. 28, no. 2, pp. 247-255, 1993.

[61] G. Suraj, C. S. P. Iyer, and M. Lalithambika, "Adsorption of cadmium and copper by modified kaolinites," Applied Clay Science, vol. 13, no. 4, pp. 293-306, 1998.

[62] S. Babel and T. A. Kurniawan, "Low-cost adsorbents for heavy metals uptake from contaminated water: a review," Journal of Hazardous Materials, vol. 97, no. 1-3, pp. 219-243, 2003.

[63] S. E. Bailey, T. J. Olin, R. M. Bricka, and D. D. Adrian, "A review of potentially low-cost sorbents for heavy metals," Water Research, vol. 33, no. 11, pp. 2469-2479, 1999.

[64] S. Qaiser, A. R. Saleemi, and M. M. Ahmad, "Heavy metal uptake by agro based waste materials," Electronic Journal of Biotechnology, vol. 10, no. 3, pp. 409-416, 2007.

[65] S. K. R. Yadanaparthi, D. Graybill, and R. von Wandruszka, "Adsorbents for the removal of arsenic, cadmium, and lead from contaminated waters," Journal of Hazardous Materials, vol. 171, no. 1-3, pp. 1-15, 2009.

[66] A. M. Urtiaga, A. Alonso, I. Ortiz et al., "Comparison of liquid membrane processes for the removal of cadmium from wet phosphoric acid," Journal of Membrane Science, vol. 164, no. 1-2, pp. 229-240, 2000.

[67] B. Swain, K. Sarangi, and R. P. Das, "Effect of different anions on separation of cadmium and zinc by supported liquid membrane using TOPS-99 as mobile carrier," Journal of Membrane Science, vol. 277, no. 1-2, pp. 240-248, 2006.

[68] H. R. Mortaheb, H. Kosuge, B. Mokhtarani, M. H. Amini, and H. R. Banihashemi, "Study on removal of cadmium from wastewater by emulsion liquid membrane," Journal of Hazardous Materials, vol. 165, no. 1-3, pp. 630-636, 2009.
[69] L. Marder, G. O. Sulzbach, A. M. Bernardes, and J. Zoppas Ferreira, "Removal of cadmium and cyanide from aqueous solutions through electrodialysis," Journal of the Brazilian Chemical Society, vol. 14, no. 4, pp. 610-615, 2003.

[70] F. J. Alguacil, "A kinetic study of cadmium(II) adsorption on Lewatit TP260 resin," Journal of Chemical Research, Synopses, no. 3, pp. 144-146, 2003.

[71] K. Rao, M. Mohapatra, S. Anand, and P. Venkateswarlu, "Review on cadmium removal from aqueous solutions," International Journal of Engineering, Science and Technology, vol. 2, no. 7, pp. 81-103, 2010.

[72] S. Islamoglu, L. Yilmaz, and H. O. Ozbelge, "Development of a precipitation based separation scheme for selective removal and recovery of heavy metals from cadmium rich electroplating industry effluents," Separation Science and Technology, vol. 41, no. 15, pp. 3367-3385, 2006.

[73] X. Lin, R. C. Burns, and G. A. Lawrance, "Heavy metals in wastewater: The effect of electrolyte composition on the precipitation of cadmium(II) using lime and magnesia," Water, Air, \& Soil Pollution, vol. 165, no. 1-4, pp. 131-152, 2005.

[74] Y. Ku, M.-H. Wu, and Y.-S. Shen, "A study on the cadmium removal from aqueous solutions by zinc cementation," Separation Science and Technology, vol. 37, no. 3, pp. 571-590, 2002.

[75] K. Takeshita, K. Watanabe, Y. Nakano, and M. Watanabe, "Extraction separation of Cd(II) and Zn(II) with Cyanex301 and aqueous nitrogen-donor ligand TPEN," Solvent Extraction and Ion Exchange, vol. 22, no. 2, pp. 203-218, 2004.

[76] B. R. Reddy, D. N. Priya, and K. H. Park, "Separation and recovery of cadmium(II), cobalt(II) and nickel(II) from sulphate leach liquors of spent Ni-Cd batteries using phosphorus based extractants," Separation and Purification Technology, vol. 50, no. 2, pp. 161-166, 2006.

[77] Z. Yuan, H. Yi, T. Wang, Y. Zhang, X. Zhu, and J. Yao, "Application of phosphate solubilizing bacteria in immobilization of $\mathrm{Pb}$ and Cd in soil," Environmental Science and Pollution Research, vol. 24, no. 27, pp. 21877-21884, 2017.

[78] L. M. Barros Júnior, G. R. Macedo, M. M. L. Duarte, E. P. Silva, and A. K. C. L. Lobato, "Biosorption of cadmium using the fungus aspergillus niger," Brazilian Journal of Chemical Engineering, vol. 20, no. 3, pp. 229-239, 2003.

[79] B. Hadi, A. Margaritis, F. Berruti, and M. Bergougnou, "Kinetics and equilibrium of cadmium biosorption by yeast cells $S$. Cerevisiae and K. Fragilis," International Journal of Chemical Reactor Engineering, vol. 1, no. 1, 2002.

[80] G. Arikpo, M. Eja, L. Ogbonnaya, and A. Opara, "Cadmium uptake by the green alga Chlorella emersonii," Global Journal of Pure and Applied Sciences, vol. 10, no. 2, pp. 257-262, 2004.

[81] Y. N. Mata, M. L. Blázquez, A. Ballester, F. González, and J. A. Muñoz, "Characterization of the biosorption of cadmium, lead and copper with the brown alga Fucus vesiculosus," Journal of Hazardous Materials, vol. 158, no. 2-3, pp. 316-323, 2008.

[82] L. Sanità Di Toppi and R. Gabbrielli, "Response to cadmium in higher plants," Environmental and Experimental Botany, vol. 41, no. 2, pp. 105-130, 1999.

[83] M. G. Yang, X. Y. Lin, and X. E. Yang, "Impact of Cd on growth and nutrient accumulation of different plant species," Chinese Journal of Applied Ecology, vol. 9, no. 1, pp. 89-94, 1998.

[84] S. L. Brown, R. L. Chaney, J. S. Angle, and A. J. M. Baker, "Phytoremediation potential of Thlaspi caerulescens and bladder campion for zinc- and cadmium-contaminated soil," Journal of Environmental Quality, vol. 23, no. 6, pp. 1151-1157, 1994. 
[85] H. Küpper, E. Lombi, F.-J. Zhao, and S. P. McGrath, “Cellular compartmentation of cadmium and zinc in relation to other elements in the hyperaccumulator Arabidopsis halleri," Planta, vol. 212, no. 1, pp. 75-84, 2000.

[86] F. J. Zhao, R. F. Jiang, S. J. Dunham, and S. P. McGrath, "Cadmium uptake, translocation and tolerance in the hyperaccumulator Arabidopsis halleri," New Phytologist, vol. 172, no. 4, pp. 646-654, 2006.

[87] G. Rossi, A. Figliolia, S. Socciarelli, and B. Pennelli, "Capability of Brassica napus to accumulate cadmium, zinc and copper from soil," Acta Biotechnologica, vol. 22, no. 1-2, pp. 133-140, 2002.

[88] H. Kubota and C. Takenaka, "Arabis gemmifera is a Hyperaccumulator of Cd and Zn," International Journal of Phytoremediation, vol. 5, no. 3, pp. 197-201, 2003.

[89] R.-L. Qiu, X. Zhao, Y.-T. Tang, F.-M. Yu, and P.-J. Hu, “Antioxidative response to $\mathrm{Cd}$ in a newly discovered cadmium hyperaccumulator, Arabis paniculata F.," Chemosphere, vol. 74, no. 1, pp. 6-12, 2008.

[90] W. Liu, W. S. Shu, and C. Y. Lan, "Viola baoshanensisda newly found Cd hyperaccumulator," Chinese Science Bulletin, vol. 48, pp. 2046-2049, 2003 (Chinese).

[91] G. De La Rosa, J. R. Peralta-Videa, M. Montes, J. G. Parsons, I. Cano-Aguilera, and J. L. Gardea-Torresdey, "Cadmium uptake and translocation in tumbleweed (Salsola kali), a potential Cd-hyperaccumulator desert plant species: ICP/OES and XAS studies," Chemosphere, vol. 55, no. 9, pp. 1159-1168, 2004.

[92] Y. H.Xiong, X. E. Yang, Z. Q. Ye, and Z. L. He, "Characteristics of cadmium uptake and accumulation by two contrasting ecotypes of Sedum alfredii Hance," Journal of Environmental Science and Health, Part A: Toxic/Hazardous Substances and Environmental Engineering, vol. 39, no. 11-12, pp. 2925-2940, 2004.

[93] S.-H. Wei and Q.-X. Zhou, "Phytoremediation of cadmiumcontaminated soils by Rorippa globosa using two-phase planting," Environmental Science and Pollution Research, vol. 13, no. 3, pp. 151-155, 2006.

[94] P. Tanhan, M. Kruatrachue, P. Pokethitiyook, and R. Chaiyarat, "Uptake and accumulation of cadmium, lead and zinc by Siam weed [Chromolaena odorata (L.) King \& Robinson]," Chemosphere, vol. 68, no. 2, pp. 323-329, 2007.

[95] Y.-L. Han, H.-Y. Yuan, S.-Z. Huang, Z. Guo, B. Xia, and J. Gu, "Cadmium tolerance and accumulation by two species of Iris," Ecotoxicology, vol. 16, no. 8, pp. 557-563, 2007.

[96] S. Wei, Q. Zhou, X. Wang, K. Zhang, G. Guo, and L. Q. Ma, "A newly-discovered Cd-hyperaccumulator Solanum nigrum L," Chinese Science Bulletin, vol. 50, no. 1, pp. 33-38, 2005.

[97] K. Peng, C. Luo, W. You, C. Lian, X. Li, and Z. Shen, "Manganese uptake and interactions with cadmium in the hyperaccumulator-Phytolacca Americana L.," Journal of Hazardous Materials, vol. 154, no. 1-3, pp. 674-681, 2008.

[98] X. Liu, K. Peng, A. Wang, C. Lian, and Z. Shen, "Cadmium accumulation and distribution in populations of Phytolacca americana L. and the role of transpiration," Chemosphere, vol. 78, no. 9, pp. 1136-1141, 2010.

[99] Y. Sun, Q. Zhou, L. Wang, and W. Liu, "Cadmium tolerance and accumulation characteristics of Bidens pilosa L. as a potential Cd-hyperaccumulator," Journal of Hazardous Materials, vol. 161, no. 2-3, pp. 808-814, 2009.

[100] H. Dai, S. Wei, I. Twardowska, R. Han, and L. Xu, "Hyperaccumulating potential of Bidens pilosa $\mathrm{L}$. for $\mathrm{Cd}$ and elucidation of its translocation behavior based on cell membrane permeability," Environmental Science and Pollution Research, vol. 24, no. 29, pp. 23161-23167, 2017.

[101] B. Nedjimi and Y. Daoud, "Cadmium accumulation in Atriplex halimus subsp. schweinfurthii and its influence on growth, proline, root hydraulic conductivity and nutrient uptake," Flora, vol. 204, no. 4, pp. 316-324, 2009.

[102] H.-L. Fan and W. Zhou, "Screening of Amaranth Cultivars (Amaranthus mangostanus L.) for Cadmium Hyperaccumulation," Agricultural Sciences in China, vol. 8, no. 3, pp. 342-351, 2009.

[103] X. Zhang, S. Zhang, X. Xu et al., “Tolerance and accumulation characteristics of cadmium in Amaranthus hybridus L.," Journal of Hazardous Materials, vol. 180, no. 1-3, pp. 303-308, 2010.

[104] Y. Tang, R. Qiu, X. Zeng et al., "Zn and Cd hyperaccumulating characteristics of picris divaricata vant," International Journal of Environment and Pollution, vol. 38, no. 1-2, pp. 26-38, 2009.

[105] C. Phaenark, P. Pokethitiyook, M. Kruatrachue, and C. Ngernsansaruay, "Cd and $\mathrm{Zn}$ accumulation in plants from the Padaeng zinc mine area.", International Journal of Phytoremediation, vol. 11, no. 5, pp. 479-495, 2009.

[106] Z. Liu, X. He, W. Chen, F. Yuan, K. Yan, and D. Tao, "Accumulation and tolerance characteristics of cadmium in a potential hyperaccumulator-Lonicera japonica Thunb," Journal of Hazardous Materials, vol. 169, no. 1-3, pp. 170-175, 2009.

[107] L.-Y. He, Z.-J. Chen, G.-D. Ren, Y.-F. Zhang, M. Qian, and X.F. Sheng, "Increased cadmium and lead uptake of a cadmium hyperaccumulator tomato by cadmium-resistant bacteria," Ecotoxicology and Environmental Safety, vol. 72, no. 5, pp. 13431348,2009

[108] S. Redondo-Gómez, E. Mateos-Naranjo, and L. AndradesMoreno, "Accumulation and tolerance characteristics of cadmium in a halophytic Cd-hyperaccumulator, Arthrocnemum macrostachyum," Journal of Hazardous Materials, vol. 184, no. 1-3, pp. 299-307, 2010.

[109] L. Buendía-González, J. Orozco-Villafuerte, F. Cruz-Sosa, C. E. Barrera-Díaz, and E. J. Vernon-Carter, "Prosopis laevigata a potential chromium (VI) and cadmium (II) hyperaccumulator desert plant," Bioresource Technology, vol. 101, no. 15, pp. 5862$5867,2010$.

[110] G. Sayyad, M. Afyuni, S. Mousavi, K. C. Abbaspour, B. K. Richards, and R. Schulin, "Transport of $\mathrm{Cd}, \mathrm{Cu}, \mathrm{Pb}$ and $\mathrm{Zn}$ in a calcareous soil under wheat and safflower cultivation- A column study," Geoderma, vol. 154, no. 3-4, pp. 311-320, 2010.

[111] L. Chen, X.-H. Long, Z.-H. Zhang, X.-T. Zheng, Z. Rengel, and Z.-P. Liu, "Cadmium Accumulation and Translocation in Two Jerusalem Artichoke (Helianthus tuberosus L.) Cultivars," Pedosphere, vol. 21, no. 5, pp. 573-580, 2011.

[112] S. Zhang, H. Lin, L. Deng et al., "Cadmium tolerance and accumulation characteristics of Siegesbeckia orientalis L.," Ecological Engineering, vol. 51, pp. 133-139, 2013.

[113] L. Lin, B. Ning, M. Liao et al., "Youngia erythrocarpa, a newly discovered cadmium hyperaccumulator plant," Environmental Modeling and Assessment, vol. 187, no. 1, article 4205, 2015.

[114] J. Nie, Y. Liu, G. Zeng et al., "Cadmium accumulation and tolerance of Macleaya cordata: a newly potential plant for sustainable phytoremediation in Cd-contaminated soil," Environmental Science and Pollution Research, vol. 23, no. 10, pp. 10189-10199, 2016.

[115] X. Li, X. Zhang, Y. Yang et al., "Cadmium accumulation characteristics in turnip landraces from China and assessment 
of their phytoremediation potential for contaminated soils," Frontiers in Plant Science, vol. 7, article 1862, 2016.

[116] T. V. Nedelkoska and P. M. Doran, "Hyperaccumulation of cadmium by hairy roots of Thlaspi caerulescens," Biotechnology and Bioengineering, vol. 67, no. 5, pp. 607-615, 2000.

[117] C. Cosio, E. Martinoia, and C. Keller, "Hyperaccumulation of Cadmium and Zinc in Thlaspi caerulescens and Arabidopsis halleri at the Leaf Cellular Level," Plant Physiology, vol. 134, no. 2, pp. 716-725, 2004.

[118] C. Lehmann and F. Rebele, "Assessing the Potential for cadmium phytoremediation with Calamagrostis epigejos: A pot experiment," International Journal of Phytoremediation, vol. 6, no. 2, pp. 169-183, 2004.

[119] Y. Sun, Q. Zhou, L. Wang, and W. Liu, "The influence of different growth stages and dosage of EDTA on Cd uptake and accumulation in Cd-hyperaccumulator (Solanum nigrum L.)," Bulletin of Environmental Contamination and Toxicology, vol. 82, no. 3, pp. 348-353, 2009.

[120] S. Wei, Q. Zhou, and P. V. Koval, "Flowering stage characteristics of cadmium hyperaccumulator Solanum nigrum L. and their significance to phytoremediation," Science of the Total Environment, vol. 369, no. 1-3, pp. 441-446, 2006.

[121] W. Xiao, D. Li, X. Ye et al., "Enhancement of Cd phytoextraction by hyperaccumulator Sedum alfredii using electrical field and organic amendments," Environmental Science and Pollution Research, vol. 24, no. 5, pp. 5060-5067, 2017.

[122] Z. Li, L. Wu, Y. Luo, and P. Christie, "Changes in metal mobility assessed by EDTA kinetic extraction in three polluted soils after repeated phytoremediation using a cadmium/zinc hyperaccumulator," Chemosphere, vol. 194, pp. 432-440, 2018.

[123] M. F. Quartacci, A. Argilla, A. J. M. Baker, and F. Navari-Izzo, "Phytoextraction of metals from a multiply contaminated soil by Indian mustard," Chemosphere, vol. 63, no. 6, pp. 918-925, 2006.

[124] X. Sheng and J. Xia, "Improvement of rape (Brassica napus) plant growth and cadmium uptake by cadmium-resistant bacteria," Chemosphere, vol. 64, no. 6, pp. 1036-1042, 2006.

[125] W. Liu, Q. Zhou, Z. Zhang, T. Hua, and Z. Cai, "Evaluation of cadmium phytoremediation potential in Chinese cabbage cultivars," Journal of Agricultural and Food Chemistry, vol. 59, no. 15, pp. 8324-8330, 2011.

[126] P. J. Khankhane, A. Tabassum, and A. Patel, "Cadmium tolerance and its enhanced accumulation potential of Arundo donax by EDTA," Journal of Environmental Biology, vol. 38, no. 2, pp. 327-334, 2017.

[127] G. P. S. Sidhu, H. P. Singh, D. R. Batish, and R. K. Kohli, "Tolerance and hyperaccumulation of cadmium by a wild, unpalatable herb Coronopus didymus (L.) Sm. (Brassicaceae)," Ecotoxicology and Environmental Safety, vol. 135, pp. 209-215, 2017.

[128] M. Wu, Q. Luo, Y. Zhao et al., "Physiological and biochemical mechanisms preventing $\mathrm{Cd}$ toxicity in the new hyperaccumulator Abelmoschus manihot," Journal of Plant Growth Regulation, pp. 1-10, 2017.

[129] P. K. Rai, "Heavy metal phytoremediation from aquatic ecosystems with special reference to macrophytes," Critical Reviews in Environmental Science and Technology, vol. 39, no. 9, pp. 697753, 2009.

[130] M. Delgado, M. Bigeriego, and E. Guarniola, "Uptake of Zn, Cr and Cd by water hyacinths," Water Research, vol. 27, no. 2, pp. 269-272, 1993.
[131] G. Wang, M. Fuerstenau, and R. Smith, "Sorption of heavy metals onto nonliving water hyacinth roots," Mineral Processing and Extractive Metallurgy Review, vol. 19, no. 1, pp. 309-322, 1998.

[132] M. E. Soltan and M. N. Rashed, "Laboratory study on the survival of water hyacinth under several conditions of heavy metal concentrations," Advances in Environmental Research, vol. 7, no. 2, pp. 321-334, 2003.

[133] V. J. Odjegba and I. O. Fasidi, "Phytoremediation of heavy metals by Eichhornia crassipes," Environment Systems and Decisions, vol. 27, no. 3, pp. 349-355, 2007.

[134] J. A. L. Dulay, E. B. Caldona, and A. R. Camacho, "Phytoremediation of Cadmium contaminated water by Hydrilla (Hydrilla verticillata," SLU Research Journal, vol. 41, no. 1, pp. 23-33, 2010.

[135] N. Noraho and J. R. Gaur, "Cadmium adsorption and intracellular uptake by two macrophytes, Azolla pinnata and Spirodela polyrhiza," Fundamental and Applied Limnology, vol. 136, no. 1, pp. 135-144, 1996.

[136] Q. Wang, Y. Cui, and Y. Dong, "Phytoremediation of polluted waters potentials and prospects of wetland plants," Acta Biotechnologica, vol. 22, no. 1-2, pp. 199-208, 2002.

[137] P. K. Rai, "Phytoremediation of $\mathrm{Hg}$ and $\mathrm{Cd}$ from industrial effluents using an aquatic free floating macrophyte Azolla pinnata," International Journal of Phytoremediation, vol. 10, no. 5, pp. 430-439, 2008.

[138] S. Das, S. Goswami, and A. D. Talukdar, "A study on cadmium phytoremediation potential of water lettuce, Pistia stratiotes L.", Bulletin of Environmental Contamination and Toxicology, vol. 92, no. 2, pp. 169-174, 2014.

[139] M. A. Maine, M. V. Duarte, and N. L. Suñé, "Cadmium uptake by floating macrophytes," Water Research, vol. 35, no. 11, pp. 2629-2634, 2001.

[140] E. J. Olguín, E. Hernández, and I. Ramos, "The effect of both different light conditions and the $\mathrm{pH}$ value on the capacity of Salvinia minima BAKER for removing cadmium, lead and chromium," Acta Biotechnologica, vol. 22, no. 1-2, pp. 121-131, 2002.

[141] A. J. Cardwell, D. W. Hawker, and M. Greenway, "Metal accumulation in aquatic macrophytes from southeast Queensland, Australia," Chemosphere, vol. 48, no. 7, pp. 653-663, 2002.

[142] Å. Fritioff and M. Greger, "Uptake and distribution of $\mathrm{Zn}, \mathrm{Cu}$, $\mathrm{Cd}$, and $\mathrm{Pb}$ in an aquatic plant Potamogeton natans," Chemosphere, vol. 63, no. 2, pp. 220-227, 2006.

[143] B. Boonyapookana, E. S. Upatham, M. Kruatrachue, P. Pokethitiyook, and S. Singhakaew, "Phytoaccumulation and phytotoxicity of cadmium and chromium in duckweed Wolffia globosa," International Journal of Phytoremediation, vol. 4, no. 2, pp. 87100, 2002.

[144] K. M. Saad-Allah and M. A. Elhaak, "Hyperaccumulation activity and metabolic responses of Solanum nigrum in two differentially polluted growth habitats," Journal of the Saudi Society of Agricultural Sciences, vol. 16, no. 3, pp. 227-235, 2017.

[145] S. Khaokaew and G. Landrot, "A field-scale study of cadmium phytoremediation in a contaminated agricultural soil at Mae Sot District, Tak Province, Thailand: (1) Determination of Cdhyperaccumulating plants," Chemosphere, vol. 138, Article ID 16430, pp. 883-887, 2015.

[146] Y. Ishii, K. Hamano, D.-J. Kang, S. Idota, and A. Nishiwaki, "Cadmium Phytoremediation Potential of Napiergrass Cultivated in Kyushu, Japan," Applied and Environmental Soil Science, vol. 2015, Article ID 756270, 6 pages, 2015. 
[147] G. Tomović, U. Buzurović, S. Đurović, D. Vicić, N. Mihailović, and K. Jakovljević, "Strategies of heavy metal uptake by three Armeria species growing on different geological substrates in Serbia," Environmental Science and Pollution Research, vol. 25, no. 1, pp. 507-522, 2018.

[148] M. Palutoglu, B. Akgul, V. Suyarko, M. Yakovenko, N. Kryuchenko, and A. Sasmaz, "Phytoremediation of Cadmium by Native Plants Grown on Mining Soil," Bulletin of Environmental Contamination and Toxicology, vol. 100, no. 2, pp. 293297, 2018.

[149] C. E. Rosenfeld, R. L. Chaney, and C. E. Martínez, "Soil geochemical factors regulate $\mathrm{Cd}$ accumulation by metal hyperaccumulating Noccaea caerulescens (J. Presl \& C. Presl) F.K. Mey in field-contaminated soils," Science of the Total Environment, vol. 616-617, pp. 279-287, 2018.

[150] M. Mench and E. Martin, "Mobilization of cadmium and other metals from two soils by root exudates of Zea mays L. Nicotiana tabacum L. and Nicotiana rustica L," Plant and Soil, vol. 132, no. 2, pp. 187-196, 1991.

[151] I. V. Seregin and V. B. Ivanov, "Is the endodermal barrier the only factor preventing the inhibition of root branching by heavy metal salts?" Russian Journal of Plant Physiology, vol. 44, no. 6, pp. 797-800, 1997.

[152] Y. Song, L. Jin, and X. Wang, "Cadmium absorption and transportation pathways in plants," International Journal of Phytoremediation, vol. 19, no. 2, pp. 133-141, 2017.

[153] N. Yamaguchi, S. Mori, K. Baba et al., "Cadmium distribution in the root tissues of solanaceous plants with contrasting root-to-shoot Cd translocation efficiencies," Environmental and Experimental Botany, vol. 71, no. 2, pp. 198-206, 2011.

[154] V. Bert, P. Meerts, P. Saumitou-Laprade, P. Salis, W. Gruber, and N. Verbruggen, "Genetic basis of Cd tolerance and hyperaccumulation in Arabidopsis halleri," Plant and Soil, vol. 249, no. 1, pp. 9-18, 2003.

[155] C. Cosio, L. DeSantis, B. Frey, S. Diallo, and C. Keller, "Distribution of cadmium in leaves of Thlaspi caerulescens," Journal of Experimental Botany, vol. 56, no. 412, pp. 765-775, 2005.

[156] S. Clemens, M. G. Palmgren, and U. Krämer, "A long way ahead: understanding and engineering plant metal accumulation," Trends in Plant Science, vol. 7, no. 7, pp. 309-315, 2002.

[157] E. Martinoia, S. Meyer, A. De Angeli, and R. Nagy, "Vacuolar transporters in their physiological context," Annual Review of Plant Biology, vol. 63, pp. 183-213, 2012.

[158] J. Zhang, E. Martinoia, and Y. Lee, "Vacuolar transporters for cadmium and arsenic in plants and their applications in phytoremediation and crop development," Plant and Cell Physiology (PCP), 2018.

[159] D. Chao, A. Silva, I. Baxter et al., "Genome-Wide Association Studies Identify Heavy Metal ATPase3 as the Primary Determinant of Natural Variation in Leaf Cadmium in Arabidopsis thaliana," PLoS Genetics, vol. 8, no. 9, p. e1002923, 2012.

[160] H. Liu, H. Zhao, L. Wu, A. Liu, F.-J. Zhao, and W. Xu, "Heavy metal ATPase 3 (HMA3) confers cadmium hypertolerance on the cadmium/zinc hyperaccumulator Sedum plumbizincicola," New Phytologist, vol. 215, no. 2, pp. 687-698, 2017.

[161] P. Halimaa, Y.-F. Lin, V. H. Ahonen et al., "Gene expression differences between noccaea caerulescens ecotypes help to identify candidate genes for metal phytoremediation," Environmental Science \& Technology, vol. 48, no. 6, pp. 3344-3353, 2014.

[162] C. Cobbett and P. Goldsbrough, "Phytochelatins and metallothioneins: roles in heavy metal detoxification and homeostasis," Annual Review of Plant Biology, vol. 53, pp. 159-182, 2002.
[163] H. Xu, C. Yu, X. Xia et al., "Comparative transcriptome analysis of duckweed (Landoltia punctata) in response to cadmium provides insights into molecular mechanisms underlying hyperaccumulation," Chemosphere, vol. 190, pp. 154-165, 2018.

[164] Q. Zhou, J.-J. Guo, C.-T. He et al., "Comparative Transcriptome Analysis between Low- and High-Cadmium-Accumulating Genotypes of Pakchoi (Brassica chinensis L.) in Response to Cadmium Stress," Environmental Science and Technology, vol. 50, no. 12, pp. 6485-6494, 2016. 

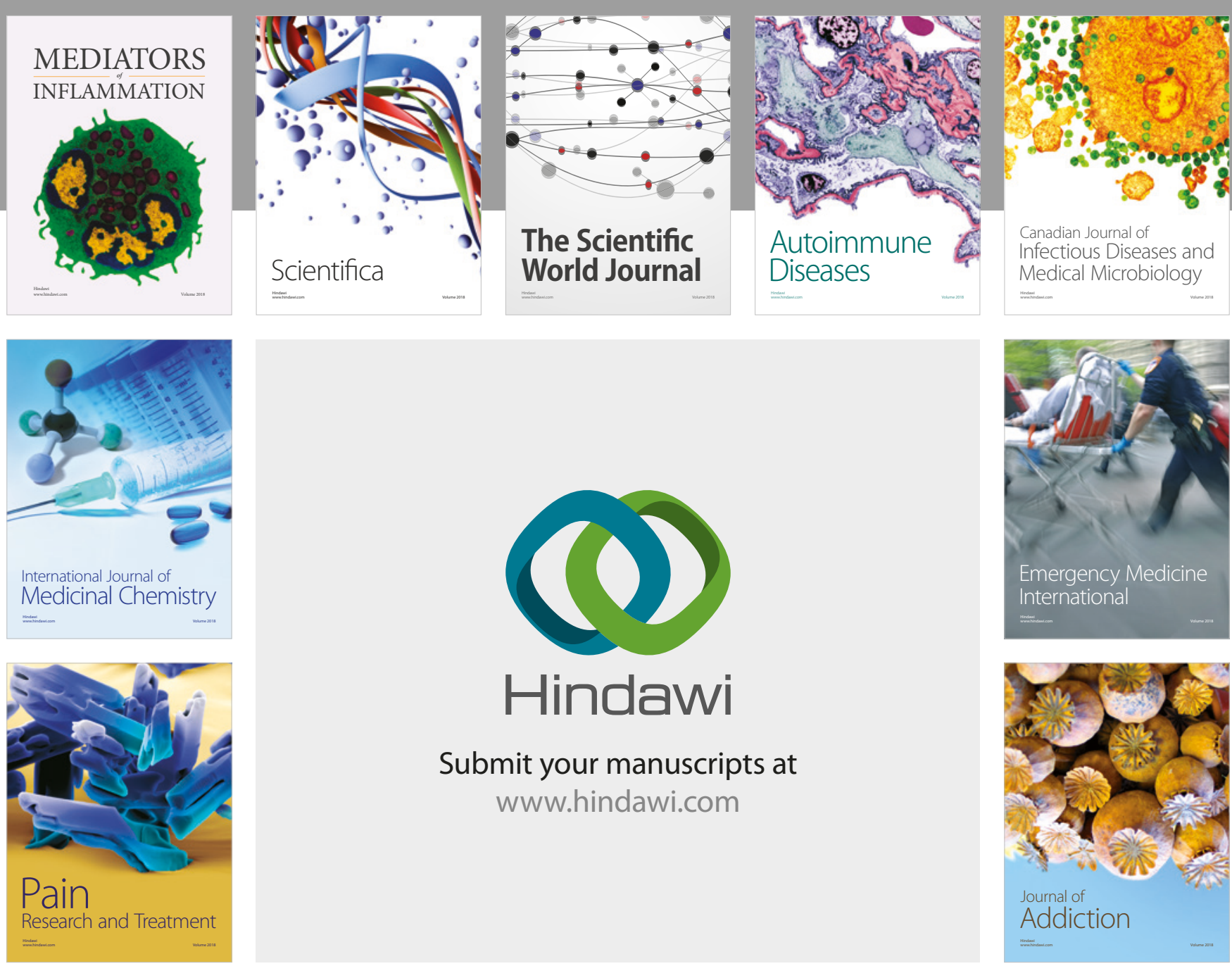

Canadian Journal of
Infectious Diseases and Medical Microbiology

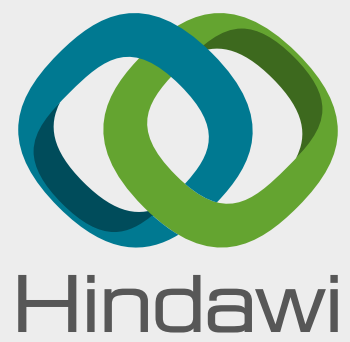

Submit your manuscripts at

www.hindawi.com
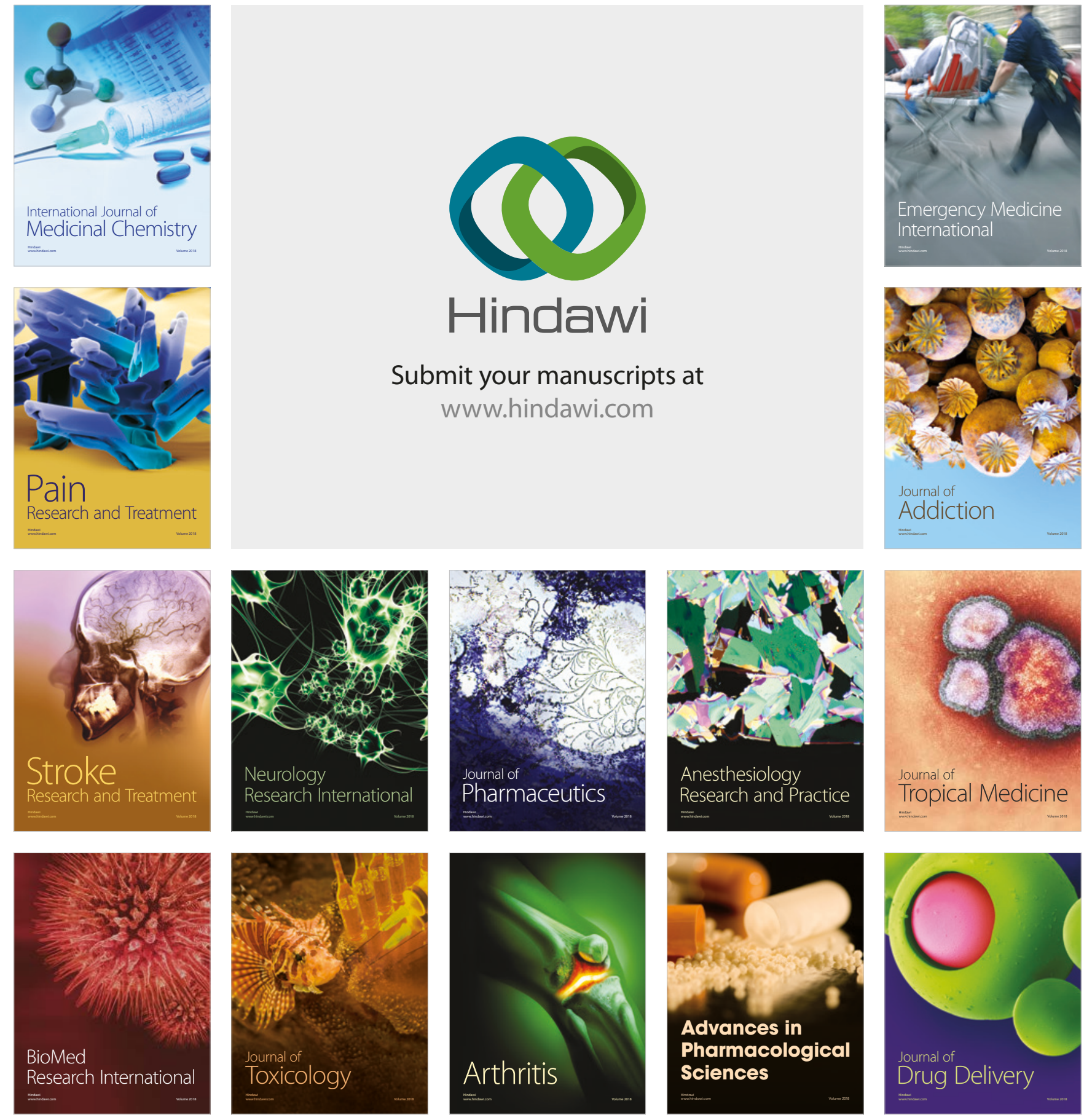